\title{
TRANVÍA MUNICIPAL Y DINÁMICA URBANA DE BOGOTÁ, 1910 - 1929 Una mirada desde el tranvía al desarrollo físico e institucional de Bogotá
}

\author{
Frasser Augusto Zambrano Salazar \\ Universidad Nacional de Colombia \\ Director de la investigación: Luis Carlos Colón Llamas \\ fazambranos@unal.edu.co
}

\section{RESUMEN}

En las primeras décadas del siglo XX Bogotá inició un proceso de cambios físicos y administrativos que difieren sustancialmente con las tendencias de la ciudad decimonónica. La investigación que se presenta procura seguir las huellas y sintetizar esta experiencia urbana a partir del tranvía municipal. Se intenta valorar este medio de transporte como uno de los principales elementos estructurantes que caracterizaron tanto el funcionamiento espacial como la dinámica socio política de la ciudad. El tranvía de origen privado devino empresa pública en 1910, consecuencia de un gran movimiento ciudadano que presionó su compra a la compañía norteamericana The Bogotá City Railway Company, constituyéndose en la primera empresa de servicios públicos de propiedad de la ciudad. Esta situación que inicialmente puso al gobierno municipal frente a dos grandes retos: el primero la consecución de $\$ 800.000$ pesos oro equivalente a $7.5 \%$ del presupuesto nacional calculado para la fecha en $\$ 10.651 .500$ y el segundo la manera de administrarla, generó dos grandes aportes para Bogotá, el primero: una empresa que representó alrededor del $42 \%$ del presupuesto municipal con rentabilidades entre el $45 \%$ y el $55 \%$ que sirvió de apoyo para el desarrollo administrativo y financiero de otras empresas del municipio y el segundo: el modelo de administración de servicios de la ciudad a través de Juntas de conformación pública y privada.

Palabras clave: Historia Urbana, Urbanismo, Bogotá, Tranvía, Redes de servicios, Municipalización

\begin{abstract}
In the first decades of the twentieth century Bogotá began a process of physical and administrative changes that differed substantially with the trends of the nineteenth century city. The research that is presented seeks to follow the traces and synthesize this urban experience from the municipal tramway. It is tried to evaluate this means of transport as one of the main structuring elements that characterized both the spatial functioning and the socio-political dynamics of the city. The tram of private origin became public company in 1910 , consequence of a great citizen movement that pressed its purchase to the North American company The Bogota City Railway Company, becoming the first public utility of property of the city. This situation that initially put the municipal government in front of two major challenges: the first achieving $\$ 800,000$ gold equivalent to $7.5 \%$ of the national budget calculated for the date at $\$ 10,651,500$ and the second the way to administer it, generated two large contributions to Bogotá, the first: a company that represented about $42 \%$ of the municipal budget with yields between $45 \%$ and $55 \%$ that served as support for the administrative and financial development of other companies in the municipality and the second: the management model of Services of the city through public and private meetings.
\end{abstract}

Key words: Urban History, Urbanism, Bogota, Tramway, Service Networks, Municipalization 


\section{INTRODUCCIÓN}

El interés de comprender el papel que desempeñó el tranvía municipal de Bogotá en la construcción, evolución física y administración de la ciudad del comienzo del siglo XX, dio origen a la investigación de la que da cuenta esta ponencia. En su desarrollo analiza el papel que cumplió este medio de transporte en la ampliación de las fronteras urbanas más allá de las limitantes naturales impuestas por las posibilidades del desplazamiento peatonal y de otros medios de transporte característicos de la ciudad decimonónica. Asimismo, estudia el legado de la empresa al fortalecimiento de otros servicios necesarios para el funcionamiento de la ciudad moderna.

La importancia del tema radica en tres aspectos que son punto de partida y referentes para su discusión; Primero: durante este periodo la empresa del tranvía fue propiedad del municipio, su administración significó un reto y una experiencia sin precedentes en el gobierno de la ciudad; segundo: fue el principal medio de transporte masivo de Bogotá cuyo impacto en el crecimiento y forma urbana fueron relevantes; tercero: el periodo constituye un hito en el crecimiento rápido y modernización de la ciudad; ésta última vista hoy en día, por algunos autores como el desarrollo de servicios públicos a través de redes y el manejo público de los mismos.

Así mismo, se destaca que en el periodo de estudio el tranvía fue significativo en la cotidianidad de los bogotanos, como lo señala el siguiente aparte del artículo de la Revista El Gráfico llamado "la resurrección del tranvía", escrito el 15 de octubre de 1910, una vez terminado el boicot mediante el cual los ciudadanos se negaron a usar el servicio para presionar la compra de la Empresa por parte del municipio a la compañía The Bogotá City Railway Company:

"De entonces al momento en que fue completada la suma, cada día parecía un siglo; [...] las distancias se alargaron como si la ciudad hubiera crecido cinco veces, y todos hacían cara de penitencia porque tenían algo así como dolor de muela en los pies." (Sánchez \& Cortés M, 1910, pág. 3)

En este contexto, la pregunta principal que busca resolver la investigación es: ¿de qué manera se relacionó la administración y construcción del tranvía municipal con la dinámica institucional, social, económica y urbanística de Bogotá, en el periodo 1910 -1929?, en respuesta se propuso la siguiente hipótesis: "la dinámica urbana de Bogotá en el periodo 1910 - 1929, estuvo relacionada con la construcción, administración y operación del tranvía municipal, empresa que dejó experiencias importantes en la conformación espacial, factiblemente en el valor del suelo y en la segregación social y fundamentalmente en la estructura institucional de la ciudad."

En concordancia se propuso explicar el papel que desempeñó el tranvía municipal durante las tres primeras décadas del siglo XX en el desarrollo urbano e institucional de Bogotá mediante la valoración de su relación con los fenómenos demográficos, físicos y administrativos significativos para la ciudad de comienzos del siglo $\mathrm{XX}$, asimismo, estudiar la manera cómo el transporte y particularmente el tranvía ayudó a tejer la trama urbana de algunos sectores de Bogotá y cotejar la participación de actores públicos y privados que trascendieron en el modelo de ciudad y la forma de administrarla y planearla.

El método de trabajo abordó el examen de elementos cuantitativos provenientes de fuentes primarias: Informes de las dependencias al Concejo Municipal y periódicos y revistas de comienzo del siglo XX, de cuyo análisis estadístico se desprende el discurso fruto que comprende los resultados de este trabajo.

\section{ESTADO DEL ARTE}

El estudio del tranvía de Bogotá se ha abordado desde diversas disciplinas entre las que se destaca la economía, la historia, el urbanismo y la geografía, entre otras. Sin embargo, se encuentra que su enfoque en la mayoría de los casos fue sectorial y no toco el impacto de la empresa en las formas de administración de la ciudad.

Desde la economía se destacan los trabajos: "Vida pasión y muerte del tranvía" (Jaramillo \& Parias, 1995) y "Economía y transporte urbano en Bogotá 1884 - 1930" (Esquivel, 1997), estos autores desarrollan a profundidad temas de econometría, con centro en la rentabilidad y productividad de la empresa, señalan el tranvía como un sistema de transporte ecológico y rentable. Empero, la municipalización como hito de 
desarrollo económico e institucional de trascendencia en el gobierno de la ciudad permanece ausente en los discursos desarrollados en esta disciplina.

Desde la Historia, son muy reconocidos: "Bogotá 450 años: retos y realidades" (Vargas \& Zambrano, 1988), "Historia del tranvía" (López \& Restrepo, 1985), "Empresas públicas de transporte en Bogotá siglo XX" (Núñez \& Rodríguez, 2003), "La ciudad de los elegidos" (Suárez, 2006). En los estudios de historia de la ciudad hay consenso en la importancia del periodo comprendido entre finales del siglo XIX y comienzos del siglo XX en el que Bogotá atravesó por un vigoroso desarrollo y crecimiento, mientras que existen diferentes enfoques sobre el papel del país en el contexto internacional y las causas de las migraciones que alimentaron el crecimiento urbano. Los autores de esta disciplina han dejado en segundo plano el papel del transporte en la construcción de la ciudad.

Desde el urbanismo se destacan: El trabajo de Juan Carlos Del Castillo "El Tránsito a la ciudad moderna 1920 - 1950" (Del Castillo, 2003), "Redes de Infraestructura y crecimiento urbano: Bogotá entre 1884 y 1951, tranvía, acueducto y energía eléctrica" (Salazar, 2008), "Bogotá: Transformaciones Urbanas y Movilidad" (Montezuma, 2000), "El Tranvía Municipal de Bogotá. Desarrollo y transición al sistema de buses municipal, 1884 - 1951" (Baquero, 2009). En los estudios de urbanismo en Colombia, la municipalización de los servicios públicos a comienzos del siglo XX, permanece ausente a pesar de constituir un proceso que en su momento marcó un hito en el gobierno de la ciudad.

En materia de cartografía son importantes los trabajos de Luis Carlos Colón Llamas: http://cartografia.bogotaendocumentos.com que contiene una recopilación de mapas y planos de la historia de la ciudad, con capas en alta resolución que permite hacer superposiciones georreferenciadas. También se destaca el Atlas Histórico de Bogotá cartografía 1791 - 2007 (Cuéllar \& Mejía, 2007).

\section{MARCO CONCEPTUAL}

En las posturas teóricas asumidas para abordar la investigación y dar una interpretación a los resultados, se tejen argumentos de autores de variadas tendencias, como Peter Hall, David Harvey, José Luis Romero, Germán Mejía, Juan Carlos Del Castillo, Alan Di Gaetano y Gabriel Dupuy entre otros, se procura desarrollar una síntesis interpretativa orientada hacia una lectura holística de los acontecimientos urbanos tanto espaciales como institucionales sucedidos en Bogotá a finales del siglo XIX, comienzos del XX, como consecuencia de la existencia y municipalización del tranvía de la ciudad.

Peter Hall plantea que en el urbanismo se mezclan la economía, la sociología y la política de las ciudades en interrelaciones infinitas (Hall, 2013, p. 15), en el mismo orden de ideas David Harvey, rechaza la visión fragmentaria de la ciudad y pugna por una visión marxista. Para Harvey "toda teoría general de la ciudad ha de relacionar, de algún modo, los procesos sociales en la ciudad con la forma espacial que la ciudad asume [...]" (Harvey, 1977) p.16. Marx propone que la existencia de la ciudad es "algo aparte de la mera aglomeración de casas independientes unas de otras. El todo en este caso no es simplemente la suma de las partes, es hasta cierto punto un organismo dotado de autonomía" (Mejía, 2000, p. 17). Asimismo, se adopta el concepto de Juan Carlos Del Castillo, quien argumenta que el transporte es uno de los elementos estructurantes de la forma urbana, señala que "el movimiento moderno planteó como uno de los soportes vitales en el planeamiento de las modernas ciudades industriales, los sistemas de transportes y los sistemas viarios" (Del Castillo, 2013, p. 51).

Partiendo de las anteriores herramientas se aborda el tranvía municipal y se llega a un sistema lleno de información que permite comprender parte del engranaje de la ciudad en el periodo; es así que el tranvía deja de ser un objeto de estudio en sí, para convertirse en un medio de acercamiento a la dinámica urbana, entendida en este trabajo como la relación de las dimensiones económica, social e institucional de los seres humanos con el territorio que transforman en procura de vivienda, equipamientos y otros intereses de coexistencia, resultado del estudio holístico presentado en la postura teórica antes mencionada.

En cuanto al contexto y caracterización histórica del periodo estudiado se acepta el planteamiento minoritario de algunos autores que caracterizan el periodo como el inicio de la modernización de la ciudad e inicio de la "planeación moderna" (Alba, 2013). Aunque para el urbanismo colombiano estos dos eventos se ubican a mediados del siglo XX (Del Castillo, 2003), en este trabajo se toma como referencia y se defiende la primera tesis, teniendo en cuenta la evolución funcional, espacial, física y administrativa de la Bogotá, en particular la extensión de las redes de servicios y la municipalización, sucedida en las tres primeras décadas del siglo XX. 
Asimismo, se entiende a Colombia como un país capitalista dado el contexto económico internacional del momento, pues si bien el desarrollo industrial de la nación fue precario para la época, es de entender que los países del tercer mundo aun en la actualidad presentan un desarrollo industrial tardío y economías desarticuladas al servicio del capital financiero internacional y los mega monopolios. Desde lo cultural, se fortalece este argumento con el planteamiento de José Luis Romero desarrollado en el libro "Latinoamérica: las ciudades y las ideas", quien plantea que el concepto de ciudad burguesa imperaba a comienzos del siglo $\mathrm{XX}$ en las ciudades latinoamericanas.

De la misma manera, dos planteamientos contemporáneos robustecen el argumento sobre el inicio de la modernización de Bogotá a comienzos del siglo XX, sin embargo, para su uso es necesario señalar que la lectura de la ciudad del pasado con herramientas o conceptos contemporáneas, a juicio del autor de este trabajo constituye una lectura válida, así como es válido el estudio de la cartografía histórica con software del presente. El primero es el de Alan Di Gaetano, para quien "Tres características básicas definen la forma moderna de la gobernanza urbana: una división clara entre los ámbitos público y privado, que en parte supone la prestación directa de servicios comunitarios por las instituciones de gobierno locales, y la formación de mecanismos institucionales para la rendición de cuentas democrática" (Di Gaetano, 2009, pág. 261). El segundo es el planteamiento de Dupuy, quien trata sobre el "urbanismo de Redes", señala que la prestación de servicios a partir de redes es una característica propia de las ciudades modernas. Para Dupuy: "El concepto de red permite centrar la cuestión al máximo. La red, como concepto y no como objeto, emerge progresivamente en la historia reciente porque plantea una nueva organización del espacio. (Dupuy, 1992, pág. 18)

\section{DINÁMICA URBANA Y MOVILIDAD}

La evolución física de la ciudad durante las a finales del siglo XIX y comienzos del XX tuvo fuertes vínculos con la construcción del tranvía, primero como orientador del desarrollo y luego de 1930 a la zaga del desarrollo urbano, como elemento estructurante. En el siguiente gráfico se observa la evolución de la red del tranvía y el crecimiento de la ciudad entre 1894 y 1938, se observa que hay una interrelación dinámica entre ciudad y tranvía.

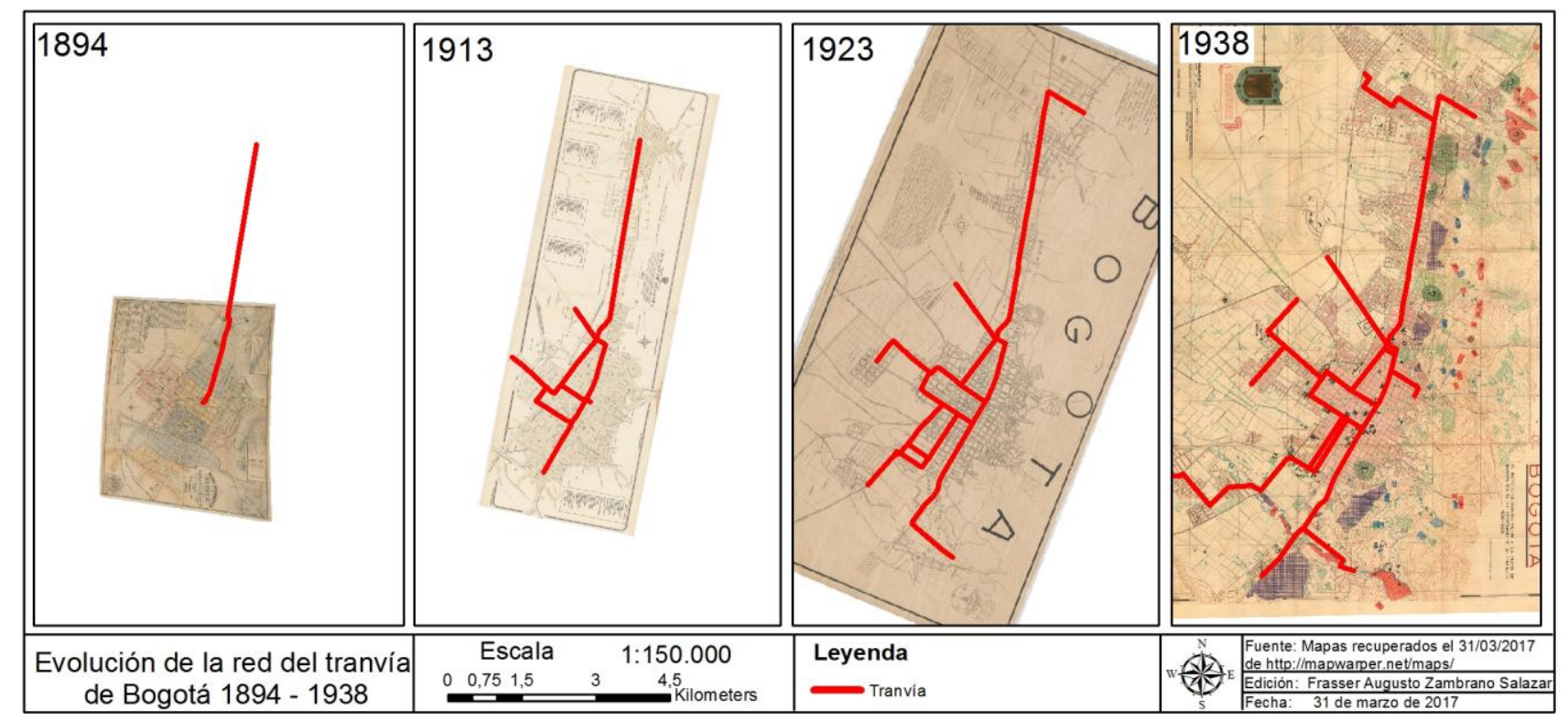

Evolución de la red del tranvía de Bogotá entre 1894 y 1938

Elaboración propia a partir de cartografía descargada de http:/mapwarper.net/maps

\subsection{Tranvía municipal y mutaciones urbanas}

El comportamiento de la densidad poblacional de Bogotá muestra tendencia a la dispersión, en la década de 1890, periodo en que entra en funcionamiento el tranvía. Hacia 1910 el tranvía de Bogotá fue un medio de 
transporte de uso común utilizado en diversas actividades y medio de integración social. El siguiente cuadro y gráfico muestran dicha relación.

\begin{tabular}{|c|c|c|c|c|}
\hline Año & Población & $\begin{array}{c}\text { Área urbanizada } \\
\text { total sin red vial } \\
\mathbf{( H a )}\end{array}$ & $\begin{array}{c}\text { Área urbanizada } \\
\text { neta } \mathbf{( H a )}\end{array}$ & $\begin{array}{c}\text { Densidad bruta sin } \\
\text { red vial (habitantes } \\
\text { por Ha) }\end{array}$ \\
\hline 1793 & 18.174 & 151 & 118 & 120 \\
\hline 1800 & 21.464 & 151 & 121 & 142 \\
\hline 1843 & 40.086 & 192 & 150 & 208 \\
\hline 1881 & 84.723 & 221 & 173 & 383 \\
\hline 1890 & 90.157 & 234 & 182 & 386 \\
\hline 1900 & 96.605 & 278 & 217 & 347 \\
\hline 1905 & 100.000 & 315 & 294 & 318 \\
\hline 1912 & 121.257 & 540 & SD & 225 \\
\hline 1918 & 143.944 & 1270 & SD & 114 \\
\hline 1927 & 235.421 & 1270 & SD & 185 \\
\hline 1938 & 330.312 & 2500 & SD & 132 \\
\hline
\end{tabular}

Evolución de la densidad poblacional de Bogotá 1884 - 1938

Elaboración propia a partir de la siguiente información: 1793, 1843, 1881, 1890, 1900, 1912, población total manzanas, Vargas J. Zambrano F, 1988, P. 19. 1800 - población, total manzanas: Puyo, F. , 1988, pp. 138- 185; población de 1918 de (Concejo Municipal de Bogotá, 1922), p. 260; población 1928 de la Dirección Departartamental de Estadística (Contraloría General de la República Dirección del Censo, 1930) p. 52 y de 1938 de (Contraloría General de la República, 1941) p. 12. Para el perímetro urbano se tuvo como referencia el Acuerdo 10 de 1902, el Acuerdo 6 de 1914, el Acuerdo 74 de 1925. Y como fuente de acercamiento a la información el Acuerdo 15 de 1940.

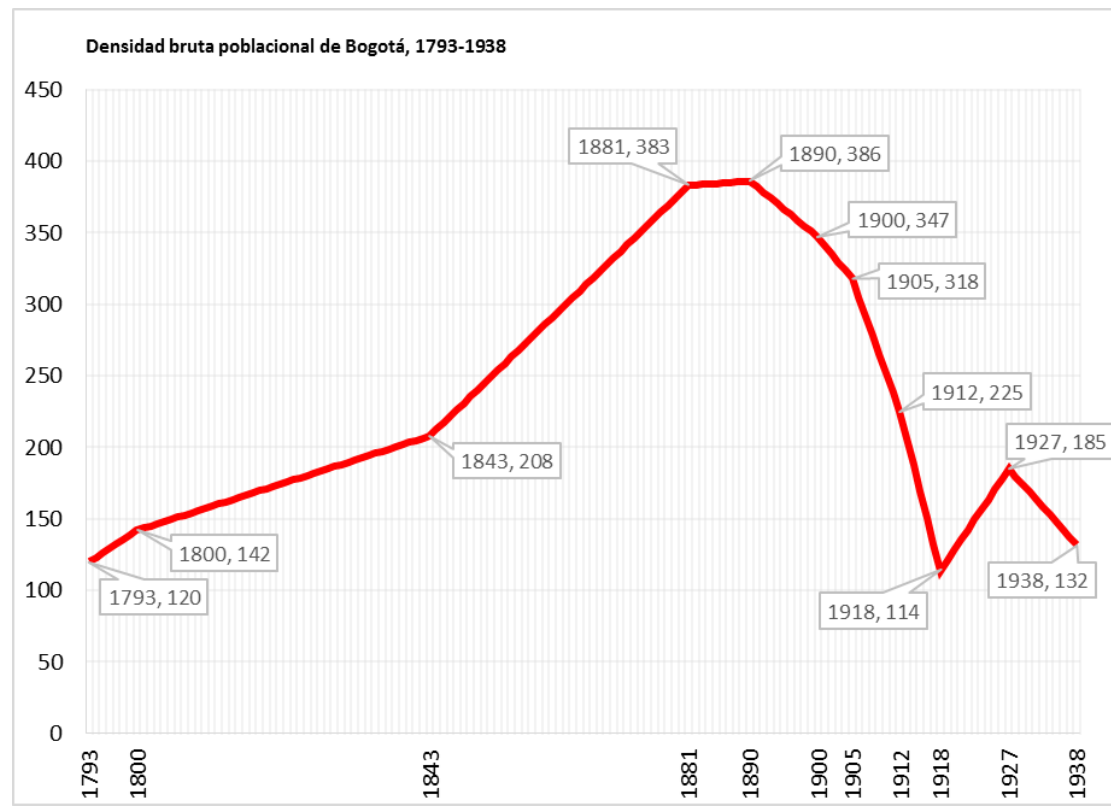

Densidad poblacional Bogotá 1793-1938

Elaboración propia a partir de la tabla anterior

La disminución de la densidad poblacional en la última década del siglo XIX, mostrada en la gráfica anterior, sin la disminución de población señala un fuerte proceso de dispersión de la ciudad. La investigación desarrollada demuestra que uno de los elementos que permitió esta dispersión en Bogotá, fue el tranvía. Antes de la aparición del tranvía la ausencia de modos de transporte masivo que facilitaran el desplazamiento de los habitantes condicionaba la concentración poblacional en el área central. Esta alta densidad y el bajo desarrollo en el manejo de residuos líquidos y sólidos, entre otros, generó crisis de salubridad que creó en la población pudiente el deseo de habitar espacios diferentes al tradicional centro colonial. Gracias al tranvía el deseo de ocupar suelos tradicionalmente utilizados como lugares de recreo por sus atractivos naturales, dotación de agua y otros elementos, Bogotá logró una redistribución poblacional y un crecimiento y dispersión de nuevos sectores.

De lo dicho por algunos historiadores, como German Mejía Pavony y Fabio Zambrano, la expansión de Bogotá, a finales del siglo XIX, comienzos del siglo XX, se puede dividir en tres etapas, la primera que 
corresponde a la compactación de las parroquias Santa Bárbara y San Victorino, como áreas residenciales antes de 1850; la segunda, la incorporación de Egipto, Las Aguas y Las Cruces como nuevas zonas urbanas, a finales del siglo XIX; y la tercera el desarrollo de periferias Chapinero, San Diego y San Cristóbal, a finales del siglo XIX y comienzos del XX. (Zambrano \& Bernard, 1993)

En la presente investigación se comparte que la primera de estas etapas corresponde a un proceso de compactación de la ciudad y sucede sin tranvía, sin embargo, se plantea que a finales de la segunda etapa está presente el tranvía y no solamente se da la incorporación de Egipto, Las Aguas y Las Cruces como nuevas zonas urbanas, sino también Chapinero como lo demuestran el Acuerdo del 17 de diciembre de 1885. Se inicia un proceso fuerte de dispersión como se observa en el estudio de densidades, coincidente con la aparición del tranvía. La tercera etapa correspondiente a comienzos del siglo XX, no solamente se da el desarrollo de las periferias de Chapinero, San Diego y San Cristóbal, sino que se rompe totalmente con las tendencias de expansión y usos del suelo presentes hasta antes del tranvía, muestra de ello es la relocalización de población soportada en el comportamiento interno de la población de Bogotá 1881- 1938, que se analiza en siguiente capítulo de esta ponencia.

Una consecuencia clara de la existencia del tranvía es el incremento del precio del suelo que en muchos casos hace que la comercialización del mismo se base en la tenencia de lotes para venderlos a futuro, generando una renta producto de la valorización ocasionada por la urbanización, consecuencia parcial de la existencia del sistema de tranvía. Las fuerzas del mercado, en este caso, es el principal actor que acude a resolver las necesidades de predios y de vivienda, para la nueva población de la ciudad, principalmente de los sectores pudientes en el Norte. Un ejemplo que da cuenta del vigor de este sector, se presenta en el folleto publicado en 1900 por Antonio Izquierdo, en el cual anuncia al público el negocio de venta de lotes para edificar, situados en la jurisdicción de la ciudad, en las localidades que ha denominado Barrio Sucre, Barrio Quesada y Barrio del Mercado, todos en la sección de Chapinero perteneciente al Barrio de Las Nieves de Bogotá. (Izquierdo, 1900, pág. 3)

A partir de 1925, con el advenimiento de los buses, el tranvía disminuyó la fuerza que tuvo a comienzos de siglo para jalonar proyectos, pero tuvo la capacidad de dispersarse hacia las zonas de crecimiento urbano, cubriendo prácticamente toda la ciudad, a pesar de los intereses privados contrarios y la fuerte competencia. Hacia esa fecha se fortalece la parcelación y el comercio inmobiliario. Principalmente mediante la usura en el comercio del suelo urbano surgieron urbanizaciones y barrios periféricos. De estos procesos urbanos sucedidos en Bogotá para el periodo en relación con el tranvía, da cuenta la Memoria Municipal de 1925 que refiere la preocupación sobre el surgimiento de lo que denominan "barrios apartados de la ciudad":

" [...]. El dueño de la urbanización compra varas de terreno a uno o dos centavos, venden parte de él a quince o veinte y se reserva el resto con la idea de aprovechar las mejoras que los compradores hagan a sus lotes, para exigir mayor precio por los demás. Los compradores de tales lotes, una vez en posesión de ellos, recuerdan no haber estipulado condiciones para desagües, pavimentos, vías de acceso y servicio de agua, y al reclamar tales servicios, el vendedor naturalmente dice que no está comprometido y que es al municipio a quien corresponde su construcción. Pretende este así que el municipio se encargue de proporcionarle grandes utilidades, en negocio para cuya realización no se ha empleado sino falsa literatura. El municipio que debe velar por la higiene y comodidad del centro poblado de la ciudad, debe según ellos, disminuir sus capacidades económicas, construyendo largas líneas de vías públicas, tranvías, servicios de agua y de desagüe, a apartadas regiones que, por muchos años no son más que una pesada carga para el bienestar público." (Concejo de Bogotá, 1929, p. 214) (subrayado fuera de texto)

Hacia 1929 se encuentra que más de un $90 \%$ las urbanizaciones en proyecto están a menos de 900 metros de la red del tranvía (véase el gráfico siguiente en el que se muestran los proyectos aprobados entre 1925 y 1929 en relación con la red del tranvía, sobre buffer de la red). El servicio que inicialmente fuera criticado como un "lujo innecesario" rápidamente se convirtió en una prioridad de toda la ciudadanía, elemento fundamental para el desarrollo de la ciudad responsable de jalonar la localización de los proyectos urbanos del periodo. A finales de esta etapa la competencia de los buses y el vehículo particular generan modos complementarios, que se aprestan a sustituir las redes rígidas por recorridos flexibles. Hasta este momento el tranvía trata de acoplarse a la forma urbana, sin embargo, deja de estar a la vanguardia del crecimiento de la ciudad, y pasa a reproducir la forma que esta adquiere. 


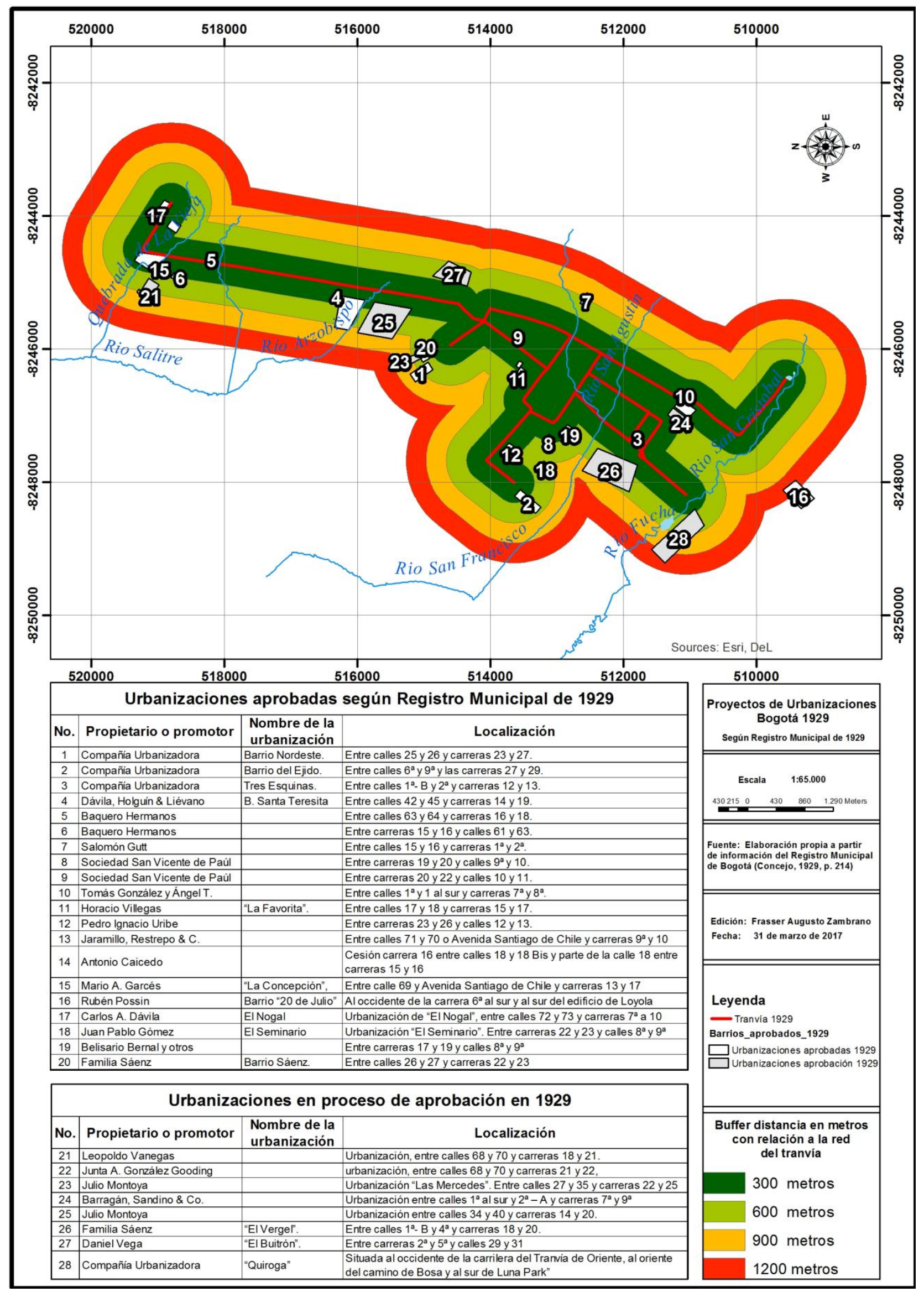

Proyectos de urbanizaciones de Bogotá en 1929

Elaboración propia a partir del Registro Municipal de 1929 
Asimismo, el mapa de 1932, ejecutado por la Sección de Obras Públicas Municipales a escala 1:10.000 o "Plano de la ciudad de Bogotá ejecutado por la sección de levantamiento de la Secretaría de OO.PP. Municipales en 1932 a escala: 1:10.000 por Julio Carvajal León y Joaquín Martínez", muestra una ciudad alargada y con la incorporación de proyectos de urbanización catalogadas como "aprobadas sin poblar", muchas de las cuales solo se construirán a mediano y largo plazo.

En la siguiente página, se presenta el mapa en mención, editado en formato SIG, al cual también se le incorporó un buffer que permite valorar las distancias de cada una de las urbanizaciones construidas y proyectadas a la fecha, permitiendo estimar la alternativa de usar el tranvía frente a la posibilidad de medios de transporte más flexibles, como los buses que para comienzos de la tercera década del siglo XX movía más pasajeros que el primero. El objeto es dimensionar el impacto del tranvía en la ubicación de las viviendas en aquel periodo. Se confirma que hacia 1932, la atracción generada por este medio de transporte a los proyectos de vivienda tiene menos trascendencia que en los periodos anteriores, se proyectan barrios muy dispersos, posiblemente por la flexibilidad de los nuevos modos de transporte, aspecto que a la vez retroalimenta la demanda de viajes y de medios de transporte con rutas flexibles. En el siguiente gráfico se observa que, de los proyectos aprobados sin construir, solo 10 de 37 urbanizaciones presentan distancia media al tranvía menor a 500 metros, mientras que existen otros que se alejan más de cuatro kilómetros de la red del tranvía, es decir más de una hora a pie, como el caso de la urbanización Rio Negro. Sin embargo, la ciudad construida hasta el momento aún está en su mayor parte cubierta por la red del tranvía.

De otra parte, de acuerdo al mapa de 1938, algunos sectores que se presentan como "planeados" en el mapa de 1932 y que para entonces se observan lejos del tranvía, ahora cuentan con el servicio. El tranvía alcanza una cobertura casi total en la ciudad. Se concluye que el proceso de urbanización a partir de la segunda década del siglo XX, sigue un orden contrario al de las primeras dos décadas, es decir el tranvía llegó después que los barrios, mientras que en la primera los barrios llegaron después del tranvía (véase la primera gráfica de este trabajo).

De acuerdo a la cartografía de la época es evidente que entre la forma de la ciudad y la forma del tranvía existió una alimentación recíproca, ya por la atracción que generaba la existencia del servicio, o por la necesidad de ampliar las redes de acuerdo a la demanda. Sin embargo al estudiar la distribución y cobertura de las redes puede otorgarse un papel trascendente al este sistema de transporte; no así a la desconcentración de actividades, pues Bogotá mantuvo su carácter de ciudad monocéntrica, las fábricas, restaurantes, cafés y el asiento de los órganos de poder municipal y nacional, continuaron principalmente implantados en el centro decimonónico de la ciudad; más aún es posible afirmar que el tranvía favoreció el modelo de ciudad monocéntrica, pues su diseño siempre estuvo orientado a unir el centro con las periferias norte, sur y occidental de la ciudad, facilitando el fortalecimiento del primero. 


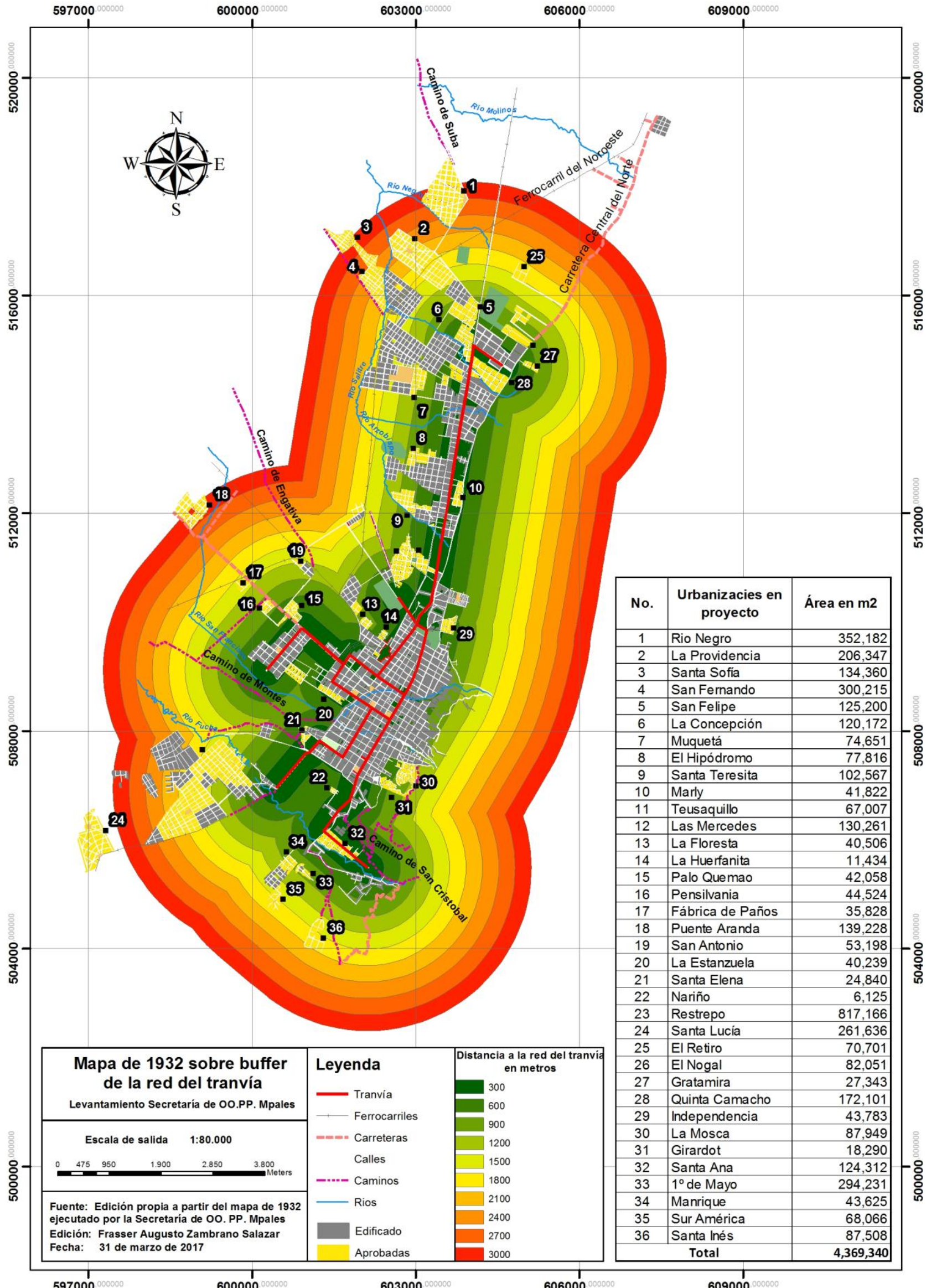

Mapa de 1932 sobre buffer de la red de tranvía

Elaboración propia a partir del mapa de 1932 de la Secretaría de OO. PP. Mpales 


\subsection{Dinámica demográfica y movilidad}

A comienzos del siglo XX, Bogotá vive un incremento demográfico mayor al de los años anteriores: de 95.761 habitantes en 1.884, remonta a 121.257 en 1.912 , 143.994 en $1.918,235.421$ en 1.928 , y 325.658 en 1.938 : crecimiento de $240 \%$ en 54 años, de los cuales $168 \%$ se dio en los últimos 16 años del periodo.

\begin{tabular}{|c|r|r|r|r|}
\hline Año & \multicolumn{1}{|c|}{ Población } & \multicolumn{1}{|c|}{ Incremento } & \multicolumn{1}{|c|}{ Años del } & Incremento \\
\hline 1,884 & 95,761 & & & \\
\hline 1,912 & 121,257 & $126.62 \%$ & 28.00 & $4.52 \%$ \\
\hline 1,918 & 143,994 & $118.75 \%$ & 6.00 & $19.79 \%$ \\
\hline 1,928 & 235,421 & $163.49 \%$ & 10.00 & $16.35 \%$ \\
\hline 1,938 & 325,658 & $138.33 \%$ & 10.00 & $13.83 \%$ \\
\hline
\end{tabular}

Población de Bogotá 1884 - 1938

Elaborada a partir de (Concejo Municipal de Bogotá, 1922), p. 260, Tomados de la Dirección Departamental de Estadística,

(Contraloría General de la República Dirección del Censo, 1930) p.52 (Contraloría General de la República, 1941) p. 12

Hacia 1912, Bogotá inicia un crecimiento poblacional acelerado y superior al resto del país, circunstancia que algunos historiadores atribuyen a las migraciones, principalmente de Boyacá y Cundinamarca (Vargas \& Zambrano, 1988), p. 22.

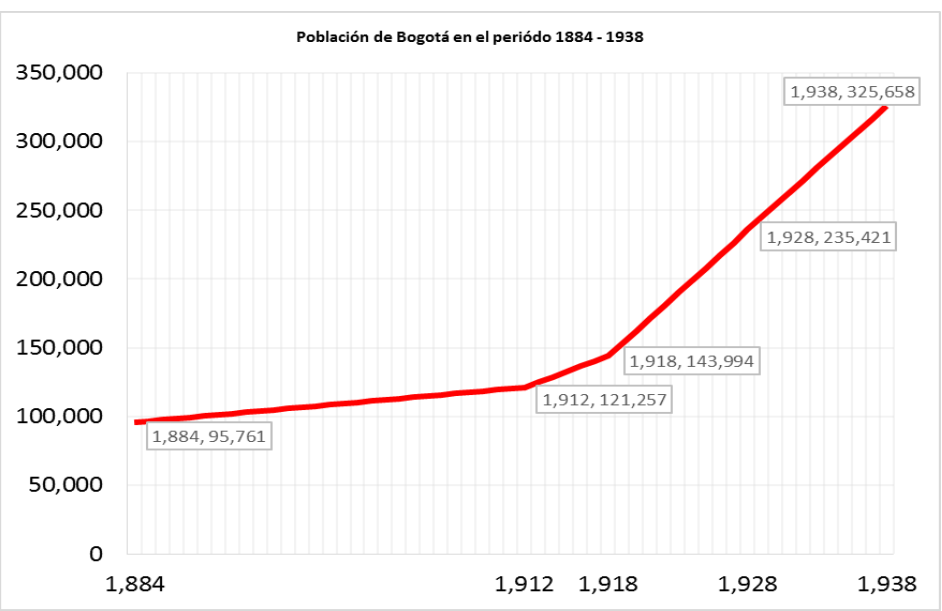

Población de Bogotá, periodo 1884 - 1938

Elaborada a partir de (Concejo Municipal de Bogotá, 1922), p. 260, Tomados de la Dirección Departamental de Estadística, (Contraloría General de la República Dirección del Censo, 1930) p.52 (Contraloría General de la República, 1941) p. 12

Dado que el periodo 1912 - 1918, rompió con las tendencias demográficas de siglos anteriores logrando un incremento de 22.737 habitantes correspondiente a $19.79 \%$ en seis años, es conveniente revisar al detalle las cifras en busca de una explicación a lo sucedido. El cuadro y gráfico siguientes, presenta el comportamiento de las estadísticas al interior de la ciudad:

\begin{tabular}{|l|r|r|}
\hline \multirow{2}{*}{ Barrio } & \multicolumn{2}{|c|}{ Población / año } \\
\cline { 2 - 3 } & 1.912 & 1.918 \\
\hline Chapinero & 7,236 & 9,277 \\
\hline Egipto & 15,572 & 17,366 \\
\hline La Catedral & 6,759 & 6,129 \\
\hline Las Aguas & 11,854 & 16,158 \\
\hline Las Cruces & 14,638 & 19,990 \\
\hline Las Nieves & 12,735 & 15,125 \\
\hline San Cristóbal (2) & $\ldots$ & 6,292 \\
\hline San Diego & 12,612 & 8,430 \\
\hline San Victoriano & 14,004 & 17,720 \\
\hline Santa Bárbara & 21,547 & 16,073 \\
\hline Sucre (2) & $\ldots$ & 7,374 \\
\hline Nazaret C & 1,964 & 2,473 \\
\hline
\end{tabular}




\begin{tabular}{|r|r|r|}
\hline Pasquilla C & 2,336 & 1,587 \\
\hline Totales & 121,257 & 143,994 \\
\hline
\end{tabular}

Población de Bogotá, periodo 1912- 1918

Elaborada a partir de (Concejo Municipal de Bogotá, 1922), p. 260, Tomados de la Dirección Departamental de Estadística, (Contraloría General de la República Dirección del Censo, 1930) p.52 (Contraloría General de la República, 1941) p. 12

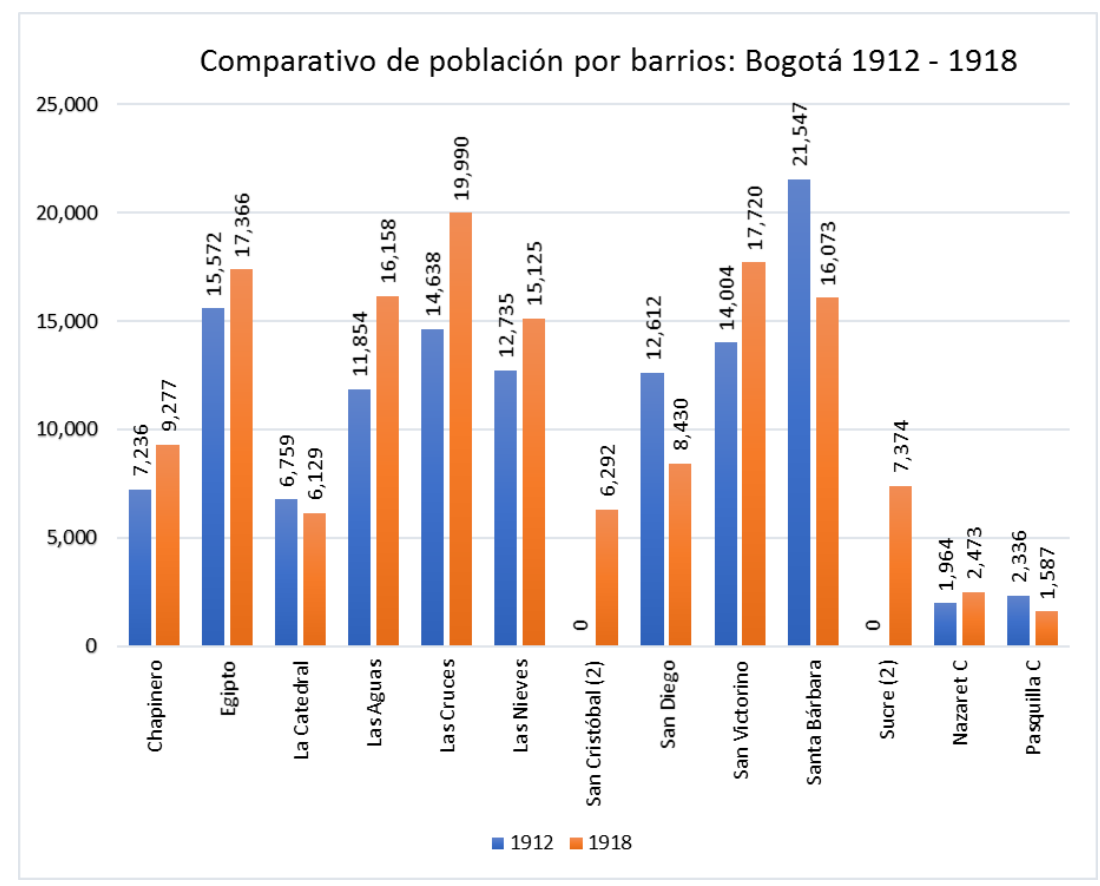

Comparativo de población por barrios, Bogotá, 1912 - 1918

Elaborada a partir de (Concejo Municipal de Bogotá, 1922, pág. 261)

De la gráfica anterior se obtiene que una parte de la ciudad creció en 33.263 personas, mientras otra parte decreció en 11.035 habitantes. Dado que el periodo es sólo de seis años, en principio no parece un comportamiento típico. Esta investigación sostiene que adicional a las migraciones antes mencionadas, sucedió una relocalización de población muy fuerte al interior de la ciudad, la cual fue posible gracias a la existencia del tranvía.

Analizando la población que creció, se encuentra que 21.059 habitantes correspondientes al $62.36 \%$ de la parte de la ciudad que incrementó su población se localizó en San Cristóbal, Sucre, Las Cruces y Chapinero. Este fenómeno es interesante dado que "hacia 1912, Sucre estaba unido a Chapinero y San Cristóbal a Las Cruces" (Concejo Municipal de Bogotá, 1922, pág. 261), es decir, los dos extremos de la ciudad. De otra parte, se encuentra que el sector que decreció, corresponde principalmente a los barrios de La Catedral, San Diego y Santa Bárbara: sector central de la ciudad. Estos aspectos están asociados probablemente a cambios significativos en el uso del suelo y la presencia del tranvía.

El comportamiento poblacional en el periodo 1912 - 1918 es un fenómeno que difiere a lo acaecido hasta 1910. Si bien, en este periodo continúa la relocalización de población de manera centrífuga, las cantidades y proporciones son totalmente superiores a las del periodo anterior. En lo espacial, los procesos se acentúan en torno a las nuevas redes de tranvía en sentido Sur Norte.

En el periodo 1910 - 1935, el número de viajes se incrementa de manera permanente y aunque aparece en escena el bus como modo alternativo, el número de pasajeros del tranvía sigue creciendo, mostrando el gran dinamismo que adquiría la ciudad.

El número de viajes (en miles) realizado por los habitantes de Bogotá entre 1910 y 1935 en transporte masivo: tranvía y bus, se presenta en los siguientes cuadro y gráfico: 


\begin{tabular}{|c|r|r|c|c|c|c|}
\hline \multicolumn{1}{c|}{ Año } & Total (en miles) & \multicolumn{2}{|l|}{ Tranvía (en miles) } & \multicolumn{2}{l|}{ Bus (en miles) } & Total, en miles \\
\hline 1,910 & 878 & 878 & $100 \%$ & - & $0 \%$ & 878 \\
\hline 1,911 & 3,547 & 3,547 & $100 \%$ & - & $0 \%$ & 3,547 \\
\hline 1,912 & 3,887 & 3,887 & $100 \%$ & - & $0 \%$ & 3,887 \\
\hline 1,913 & 4,567 & 4,567 & $100 \%$ & - & $0 \%$ & 4,567 \\
\hline 1,914 & 5,326 & 5,326 & $100 \%$ & - & $0 \%$ & 5,326 \\
\hline 1,915 & 5,480 & 5,480 & $100 \%$ & - & $0 \%$ & 5,480 \\
\hline 1,916 & 6,065 & 6,065 & $100 \%$ & - & $0 \%$ & 6,065 \\
\hline 1,917 & 6,985 & 6,985 & $100 \%$ & - & $0 \%$ & 6,986 \\
\hline 1,918 & 6,886 & 6,886 & $100 \%$ & - & $0 \%$ & 6,886 \\
\hline 1,919 & 8,035 & 8,035 & $100 \%$ & - & $0 \%$ & 8,035 \\
\hline 1,920 & 10,179 & 10,179 & $100 \%$ & - & $0 \%$ & 10,179 \\
\hline 1,921 & 10,413 & 10,413 & $100 \%$ & - & $0 \%$ & 10,413 \\
\hline 1,922 & 12,000 & 12,000 & $100 \%$ & - & $0 \%$ & 12,000 \\
\hline 1,923 & 12,669 & 12,669 & $100 \%$ & - & $0 \%$ & 12,669 \\
\hline 1,924 & 13,338 & 13,338 & $100 \%$ & - & $0 \%$ & 13,338 \\
\hline 1,925 & 14,412 & 14,412 & $100 \%$ & - & $0 \%$ & 14,412 \\
\hline 1,926 & 15,048 & 15,048 & $100 \%$ & - & $0 \%$ & 15,048 \\
\hline 1,927 & 21,397 & 16,863 & $78.81 \%$ & 4,534 & $21.19 \%$ & 21,397 \\
\hline 1,928 & 25,418 & 19,561 & $76.96 \%$ & 5,857 & $23.04 \%$ & 25,418 \\
\hline 1,929 & 33,432 & 19,932 & $59.62 \%$ & 13,500 & $40.38 \%$ & 33,432 \\
\hline 1,930 & 34,880 & 18,329 & $52.55 \%$ & 16,551 & $47.45 \%$ & 34,880 \\
\hline 1,931 & 32,625 & 18,502 & $56.71 \%$ & 14,123 & $43.29 \%$ & 32,625 \\
\hline 1,932 & 34,400 & 17,755 & $51.61 \%$ & 16,645 & $48.39 \%$ & 34,400 \\
\hline 1,933 & 37,717 & 19,565 & $51.87 \%$ & 18,152 & $48.13 \%$ & 37,717 \\
\hline 1,934 & 39,278 & 22,639 & $57.64 \%$ & 16,639 & $42.36 \%$ & 39,278 \\
\hline 1,935 & 54,149 & 23,764 & $43.89 \%$ & 30,385 & $56.11 \%$ & 54,149 \\
\hline
\end{tabular}

Pasajeros transportados por el tranvía y los buses 1910 - 1929

Elaborada a partir informe municipal (Concejo Municipal de Bogotá, 1919) p. 48, (Concejo Municipal de Bogotá, 1925) p. 140. De 1910 a 1919, se tomó los datos de Informe del Presidente del Concejo Municipal de Bogotá, doctor Zoilo E. Cuéllar ante la misma Corporación sobre las tareas de esta en su periodo del 19 de noviembre de 1917 a 31 de octubre de 1919, Informe 1917-1919, Bogotá Imprenta Municipal, 1919, pág. 48. De 1920 a 1924 se tomó la información de (Esquivel, 1997), pág. 51. De 1925 a 1927, se tomó del Anuario Municipal de Estadísticas de la Contraloría Municipal año 1948, julio de 1949 y de 1927 a 1935 del Anuario Municipal de Estadísticas, 1952, p. XIII y pág. 172-173



Pasajeros transportados por el tranvía y los buses 1910 - 1935

Elaborada a partir del cuadro anterior

En la figura anterior, en azul están representados los viajes realizados en tranvía y en café los viajes en bus. Se destaca que durante todo el periodo crece el total número de viajes de los dos modos de transporte analizados, se observa que desde 1934 el número de viajes realizado en bus supera el número de viajes realizado en tranvía. Entre 1.920 y 1.924 se presenta un incremento de viajes de 31\%, en cuatro años, cifra superior al crecimiento poblacional que según proyecciones sería del $22 \%$, en el mismo lapso de tiempo, se encuentra que hubo un mayor uso del sistema ocasionado tal vez mayor dinamismo en la ciudad.

La tabla siguiente muestra como de 62.73 viajes por persona año en 1920, se aumentó a 67.08 en 1924 , incremento que corresponde a $6.9 \%$. La causa puede estar en el cambio de las actividades económicas y la existencia de mayor dinero dado que fue la época de la danza de los millones y la bonanza cafetera. 


\begin{tabular}{|c|c|c|c|}
\hline Año & Viajes & Habitantes proyectados & viajes por persona \\
\hline 1920 & $10,179,000$ & 162,279 & 62.73 \\
\hline 1921 & $10,413,000$ & 171,422 & 60.74 \\
\hline 1922 & $12,000,240$ & 180,565 & 66.46 \\
\hline 1923 & $12,669,000$ & 189,708 & 66.78 \\
\hline 1924 & $13,338,000$ & 198,850 & 67.08 \\
\hline Total & $58,599,240$ & & \\
\hline
\end{tabular}

Viajes por persona 1920 - 1924

Nota: Elaborada a partir de informe municipal de 1925

\section{LA EMPRESA DEL TRANVÍA}

En este aparte se analiza la Empresa del Tranvía desde dos dimensiones: la primera comprende la base económica y la segunda la superestructura administrativa; con centro en la forma de administración del tranvía durante el tiempo en el que ésta perteneció a la ciudad. El periodo inicia en 1910 a partir del traspaso que por presión social realizó a Bogotá The Bogotá City Railway Company y termina en 1929 con el inicio de la administración delegada a los bancos.

El tranvía de Bogotá tiene su origen en el sector privado de ahí pasa al sector público y luego de varios periodos itinerantes de esplendor y crisis desaparece, por decisiones soportadas en intereses particulares. Este esquema general fue el desarrollado en otras ciudades latinoamericanas y colombianas, como: Rio de Janeiro, Ciudad de México, Medellín, Barranquilla, Pereira, Cartagena, entre otras.

Los antecedentes de la empresa del tranvía de Bogotá, se remontan al 28 de octubre de 1882, el Concejo de Bogotá aprobó el contrato suscrito entre William Randall y Próspero Pereiro, Secretario de Gobierno del Estado Soberano de Cundinamarca el 30 de septiembre de 1882, mediante el cual Randall, "[...] se obliga para con el Gobierno Municipal a establecer para el servicio público en esta ciudad, en alguna o algunas de las calles o carreras de aquellas que no estén declaradas parte de las vías públicas del Estado, ferrocarriles urbanos el sistema y el modo usados en Nueva York [...]"(Acuerdo 22, 1882).

El desarrollo del contrato fue controversial, Randall inició incumpliendo los plazos establecidos, con lo cual debía pagar multa de quinientos pesos $\$ 500$ a favor del Municipio, sin embargo, el Concejo mediante Acuerdo No. 12 el 6 de noviembre de 1883, prorrogó "por tres meses más, el plazo concedido para dar comienzo a la obra de los tranvías" (Acuerdo 12,1883) y exoneró al contratista de la multa. Éste el inicio de varios favorecimientos a la Empresa, que, junto a otros elementos alimentaron la indignación social. Los derechos y obligaciones adquiridos por Randall los traspasó a The Bogotá City Railway Company, con domicilio en New York, representada por James Davies, en noviembre de 1884. Con el documento de traspaso se "aclaró" y "adicionó" algunos elementos del contrato aprobado mediante Acuerdo 22 de 1882 . El municipio renuncia a "toda acción" que tuviera contra The Bogotá City Railway Company y específicamente a la indemnización de perjuicios. (Junta de Administración del Tranvía, 1918).

El servicio prestado por The Bogotá City Railway Company, en sus inicios fue orgullo para las élites bogotanas, sin embargo, decayó en su funcionamiento: "un viaje a Chapinero podía demorarse hasta dos horas, si se contaba con los accidentes, las averías tanto de los carros como de la línea" (Junta de Administración del Tranvía, 1918, p 60). De otra parte, la prepotencia de los representantes de The Bogotá City Railway Company, de la que hablaran los periódicos de Bogotá en aquella época como: El Porvenir: marzo - abril de 1910, el diario El Domingo del 20 de julio de 1910 y El Gráfico No. 13 del 15 de octubre de 1910, p.1-3, entre otros, llevó a la incomodidad de la ciudadanía. En el Concejo Municipal se debatían varias alternativas, para mejorar la condición asumida por la Ciudad ante The Bogotá City Railway Company, los cuales iban desde modificar o anular el contrato hasta comprar la empresa (Concejo Municipal, 1910, pág. 275)

El 7 de marzo de 1910 el postillón de la línea de Chapinero golpeó a un muchacho, éste acudió a un policía a denunciar al postillón agresor quien salió en su defensa en consecuencia uno de los empresarios maltrató al policía. Estos hechos rebosaron la copa de los bogotanos quienes se negaron a usar el tranvía.

El boicot permaneció hasta cuando el municipio compró y puso en funcionamiento el Tranvía el 9 de octubre de 1910. La revista el Gráfico del 15 de octubre de 1910, en el artículo "la resurrección del tranvía", señala que "Después de tanta espera, los tranvías empezaron a rodar el domingo, pero es casi de programa que los domingos llueve y aquel día el cordonazo de San Francisco fue desde las tres una verdadera lavada. Tal cual 
pantorrilla presentable, uno que otro chiste de bola a bola en los zaguanes y muchos millones de microbios que iban atropellándose aguas abajo por estas calles como si se tratara de mitin en Jaiba; eso fue todo [...] La verdadera fiesta por haber resucitado los tranvías fue el lunes. Los eléctricos muy nuevos y elegantones al andar; los otros haciendo lo que podían, apachurraditos, con apariencia de cangrejos ferroviarios. En San Francisco, gente y más gente, caras alegres, hormigueo, asaltos y apretujones; carro que llegaba era algo así como la nave de la Nación el siete de agosto: unos a subir antes que los otros bajaran. Estos á (sic) no bajar para que aquellos no subieran; sólo que allí cuanta más gente mejor y el carro acababa por llevar contentísimos á (sic) los que habían venido y a los que se iban" (Sánchez \& Cortés M, 1910, pág. 1-3)

\subsection{Aspectos Económicos del Tranvía Municipal}

La revista El Gráfico del 15 de octubre de 1910, señala que "en tanto, el todo Bogotá, contentísimo con haber sacudido coûte que coûte la ofensiva Railway Co., usa día y noche los vehículos municipales echando al aire sus aleluyas por la resurrección del tranvía" (Sánchez \& Cortés M, 1910, pág. 3), y no es para menos, en términos de la misma revista el municipio tuvo que "sudar vinagre", para conseguir el dinero necesario para adquirir la empresa. (Sánchez \& Cortés M, 1910, pág. 1-3. A pesar de las pésimas condiciones en que fue entregada la empresa al municipio, en dos años ya era significativa la importancia para la economía de la ciudad. Véase los siguientes cuadros y gráficos.

\begin{tabular}{|l|r|r|}
\hline Rentas municipales & $\mathbf{1 , 9 1 2}$ & $\mathbf{1 , 9 1 4}$ \\
\hline Empresas de Tranvía Municipal & $196,960.39$ & $264,000.00$ \\
\hline Otras rentas municipales & $268,423.55$ & $330,820.16$ \\
\hline Total, Rentas Municipales & $465,383.94$ & $594,820.16$ \\
\hline Participación del tranvía & $42.32 \%$ & $44.38 \%$ \\
\hline
\end{tabular}

Rentas municipales de Bogotá 1912 - 1914

Nota: Elaborada a partir del Mensaje del Alcalde de Bogotá al Concejo Municipal de Bogotá, acompañando al presupuesto de rentas y gastos del municipio en 1914, pág. 13

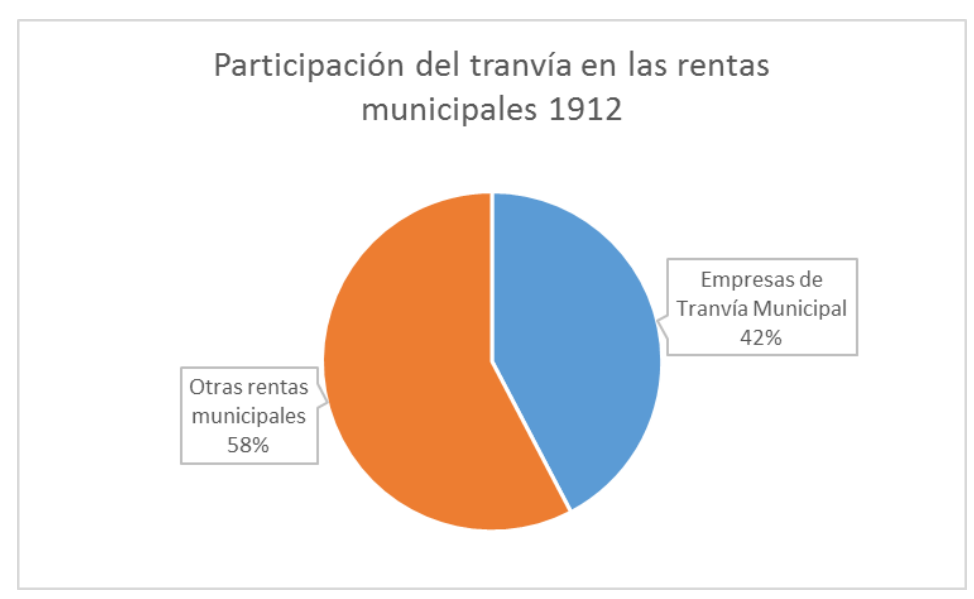

Participación del Tranvía en las Rentas Municipales de Bogotá 1912

Elaborada a partir del Mensaje del Alcalde de Bogotá al Concejo Municipal de Bogotá, acompañando al presupuesto de rentas y gastos del municipio en 1914, p.13 


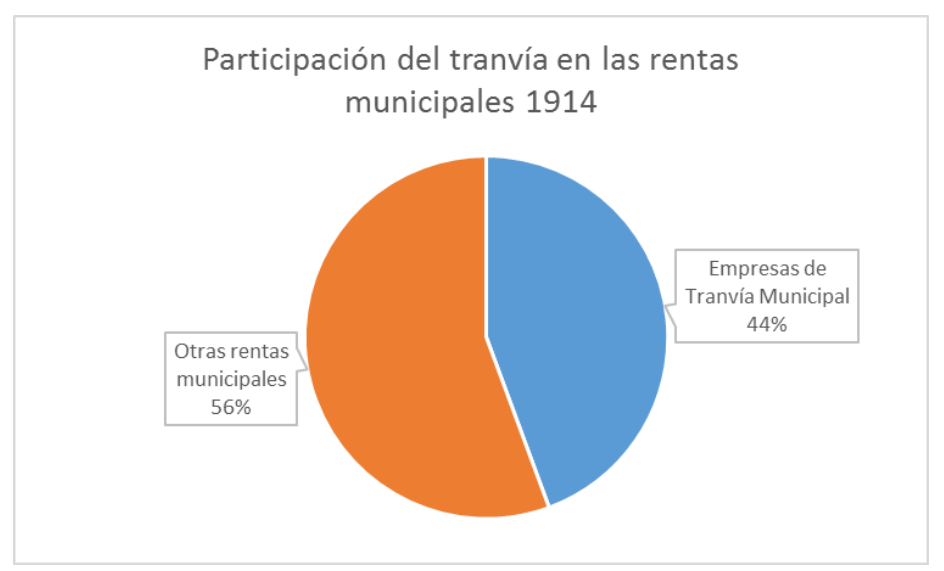

Participación del Tranvía en las Rentas Municipales de Bogotá 1914

Elaborada a partir del Mensaje del Alcalde de Bogotá al Concejo Municipal de Bogotá, acompañando al presupuesto de rentas y gastos del municipio en 1914, pág. 13

La participación del tranvía en las rentas municipales que pasa del $43 \%$ en 1912 a $44 \%$ en 1914, se mantiene hacia 1925, fecha en que representa el $43 \%$ de las rentas del municipio, ver la tabla y figuras siguientes

\begin{tabular}{|l|r|}
\hline \multicolumn{1}{|c|}{ Empresa } & \multicolumn{1}{c|}{ Presupuesto } \\
\hline Tranvía & 715.625 \\
\hline Acueducto & 392.000 \\
\hline Plazas & 110.854 \\
\hline Mataderos & 16.088 \\
\hline Impuesto predial & 174.351 \\
\hline Servicio de aseo & 158.011 \\
\hline Servicio de alumbrado y vigilancia & 79.005 \\
\hline Arrendamiento casa policía nacional & 12.000 \\
\hline Total & $\$ 1.657 .934$ \\
\hline
\end{tabular}

Presupuesto de Bogotá vigencia 1924

Elaborada a partir de (Alcaldía Municipal de Bogotá, 1924, pág.257)

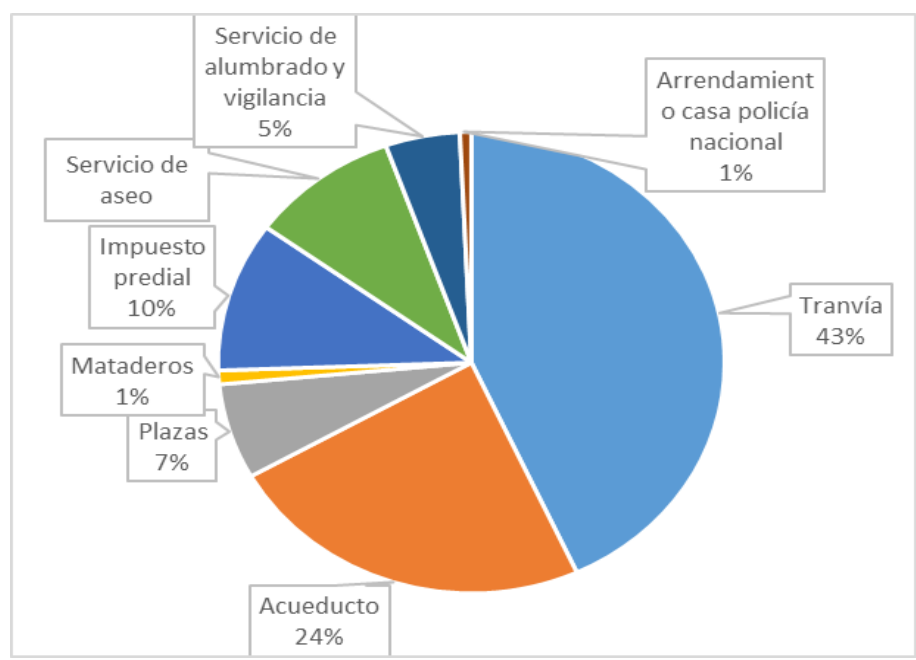

Participación del Tranvía en las Rentas Municipales de Bogotá 1924 Elaborada a partir de (Alcaldía Municipal de Bogotá, 1924, pág.257)

Los siguientes cuadro y gráfico representar los ingresos, gastos y utilidades del tranvía en la que llama la atención los años 1923, porque los rendimientos pasan a ser menores que los gastos y 1925, año en que la relación rendimiento gasto es la más extrema de todo el periodo. 


\begin{tabular}{|r|r|r|r|r|r|}
\hline Año & Productos brutos & Gastos de & Rendimientos & Porcentaje de & \multicolumn{1}{c|}{ Productos } \\
\hline 1909 & $139,440.45$ & - & - & - & - \\
\hline 1910 & $44,085.14$ & $14,607.52$ & $29,477.62$ & $33.13 \%$ & $66.87 \%$ \\
\hline 1911 & $178,598.67$ & $86,226.54$ & $92,372.13$ & $48.28 \%$ & $51.72 \%$ \\
\hline 1912 & $196,960.39$ & $93,384.01$ & $103,576.38$ & $47.41 \%$ & $52.59 \%$ \\
\hline 1913 & $230,916.17$ & $108,133.88$ & $122,782.29$ & $46.83 \%$ & $53.17 \%$ \\
\hline 1914 & $269,088.41$ & $119,789.52$ & $149,298.89$ & $44.52 \%$ & $55.48 \%$ \\
\hline 1915 & $282,774.75$ & $120,349.63$ & $162,425.12$ & $42.56 \%$ & $57.44 \%$ \\
\hline 1916 & $304,529.00$ & $136,024.60$ & $168,504.40$ & $44.67 \%$ & $55.33 \%$ \\
\hline 1917 & $346,634.35$ & $152,590.61$ & $194,043.74$ & $44.02 \%$ & $55.98 \%$ \\
\hline 1918 & $345,091.76$ & $159,953.92$ & $185,137.85$ & $46.35 \%$ & $53.65 \%$ \\
\hline 1919 & $401,991.90$ & $177,948.10$ & $224,043.80$ & $44.27 \%$ & $55.73 \%$ \\
\hline 1920 & $511,805.72$ & $244,357.62$ & $267,448.10$ & $47.74 \%$ & $52.26 \%$ \\
\hline 1921 & $516,578.82$ & $250,710.03$ & $265,868.79$ & $48.53 \%$ & $51.47 \%$ \\
\hline 1922 & $595,834.76$ & $279,691.96$ & $316,142.80$ & $46.94 \%$ & $53.06 \%$ \\
\hline 1923 & $635,570.45$ & $297,355.30$ & $338,215.15$ & $46.79 \%$ & $53.21 \%$ \\
\hline 1924 & $666,409.56$ & $401,451.14$ & $264,958.42$ & $60.24 \%$ & $39.76 \%$ \\
\hline 1925 & $735,983.20$ & $511,113.67$ & $224,869.53$ & $69.45 \%$ & $30.55 \%$ \\
\hline 1926 & $763,842.49$ & $429,393.54$ & $334,448.95$ & $56.21 \%$ & $43.79 \%$ \\
\hline 1927 & $853,874.11$ & $470,549.68$ & $383,324.43$ & $55.11 \%$ & $44.89 \%$ \\
\hline 1928 & $919,452.75$ & $574,672.54$ & $344,780.21$ & $62.50 \%$ & $37.50 \%$ \\
\hline 1929 & $1,014,103.00$ & $652,326.11$ & $361,776.89$ & $64.33 \%$ & $35.67 \%$ \\
\hline
\end{tabular}

Productos y gastos del tranvía 1909 - 1929

La información de 1909 a 1914, fue tomada de Informe presentado por la Junta del Tranvía al Concejo Municipal en 1915, pág. 15; La información de 1915 a 1918 fue tomada de Informe del Presidente del Concejo Doctor Zoilo E. Cuellar B. Ante la misma corporación, sobre las tareas de esta en su periodo del 19 de noviembre de 1917 a 31 de octubre de 1919, Municipal de Bogotá, 1917-1919 p. 48; la información de 1919 y la de 1924 - 1929, fue toma del Anuario Municipal de Estadística de la Dirección Nacional de Estadística de la Oficina Municipal Bogotá Colombia, p. 172; la información de 1920 a 1923 fue tomada de Memoria Municipal de Bogotá Correspondiente al Bienio de 1923 a 1925 Bogotá, imprenta municipal 1925, página 141

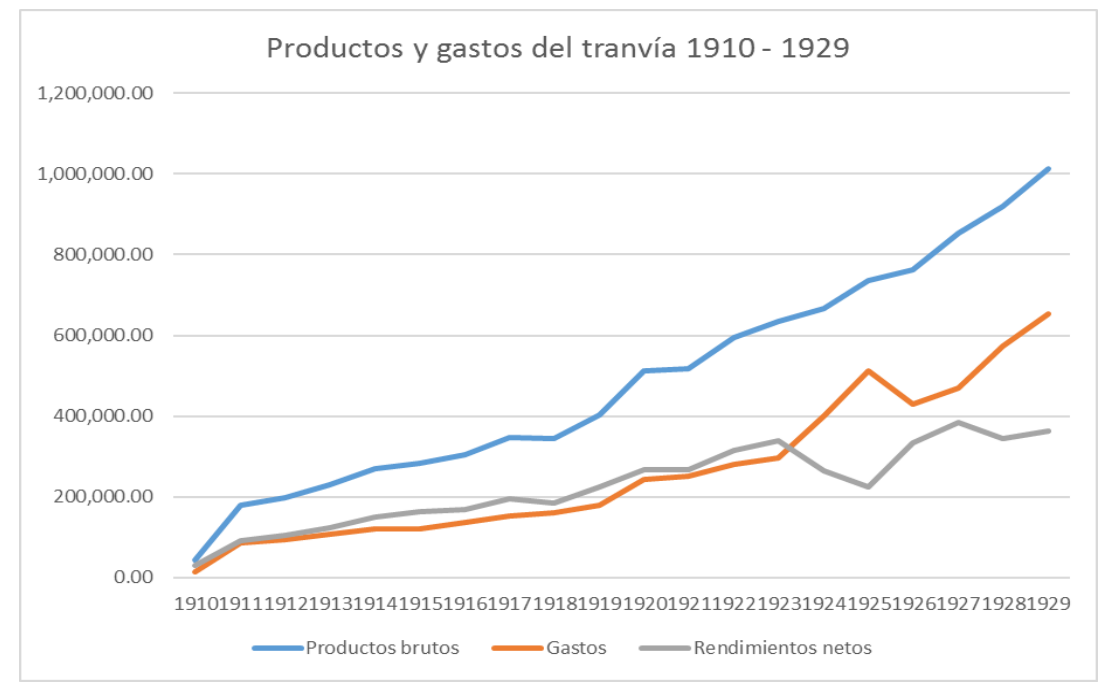

Productos y gastos del tranvía 1909 - 1929

Elaborada a partir de Informe de la tabla anterior

El músculo económico que permitió el funcionamiento de la empresa fue el préstamo, se identifican, cuatro momentos, correspondientes a cuatro modalidades de créditos a saber: i) El empréstito de 1910 para adquirir el Tranvía, ii) El crédito de 1921 denominado los bonos del Tranvía, iii) Crédito de la Casa Bancaria Dillon Read \& Co de 1924 y iv) Crédito de los bancos de Bogotá, Colombia e Hipotecario de Colombia.

\subsubsection{Empréstito de 1910 para adquirir el tranvía}

Mediante el Acuerdo 27 de 1910, el Concejo de Bogotá determinó la compra de la empresa del Tranvía y dispuso la manera de organizarla y administrarla. El artículo 1, establece: "Solicitar a los bancos establecidos en la ciudad y de los particulares, un empréstito por la suma de ochocientos mil pesos oro americano (\$800.000) a un interés no mayor del doce por ciento anual, previa autorización del Gobierno Nacional, al tenor de lo estudiado en los artículos 18 y 19 de la Ley 20 de 1908" (Acuerdo 27, 1910, Art.1). Para responder 
con la deuda, el Concejo se obliga a dar como garantía la Empresa del Tranvía, una vez que la adquieran en propiedad y responderá además con todas las rentas y bienes del municipio (Acuerdo 27, 1910), Art. 1.

Hacia 1915, permanecía el esquema financiero establecido en 1910, en el informe presentado en noviembre, la Junta del Tranvía, resalta el cumplimiento en el pago de los intereses e informa que la suma cancelada hasta el 31 de octubre por este concepto es de $\$ 466.061 .04$, cifra que corresponde a más de la mitad del capital inicial. Ese mismo año la Junta Administradora del tranvía, con autorización del Concejo Municipal, estableció en el presupuesto un valor de $\$ 22.830$ para dar principio a la amortización del empréstito de los $\$ 800.000$ de la compra, para lo cual consideró necesario unificar la moneda en que se obtuvo el empréstito para la compra, lo cual se realizó a través del Acuerdo 11 de 1915. El artículo 8 del mencionado Acuerdo, establece que "la Junta Administradora del Tranvía destinará en sus presupuestos anuales el 7\%, para amortizar los títulos expedidos por medio de sorteos trimestrales que se harán públicamente y con previo aviso, por la Administración del Tranvía. El título sorteado dejará de ganar interés quince días después de publicado el resultado del sorteo" (Junta Administradora del Tranvía, 1915, p.9)

\subsubsection{El crédito de 1.921, Los Bonos del Tranvía Municipal}

De acuerdo con los Informes del Concejo de 1924, al iniciar sus labores el Concejo elegido en octubre de 1921, encontró el crédito municipal desventajoso, por la falta de orden y eficiencia que según su concepto "imperaban en la administración de la ciudad". Las libranzas municipales, que ganan intereses a razón de 12 por 100 anual, pagaderos mensualmente, se cotizaban con 24 por 100 de descuento; los vales municipales que ganan el 10 por 100 anual, pagaderos por semestres vencidos, con 33 por 100 de descuento; y las órdenes de pago con 15 por 100 de descuento, debido a la demora más o menos larga con que eran cubiertas. (Alcaldía Municipal de Bogotá, 1924, p. 109). Véase el siguiente cuadro:

\begin{tabular}{|l|r|}
\hline Beneficiario & \multicolumn{1}{|c|}{ Valor } \\
\hline Libranzas & 169.081 .78 \\
\hline Órdenes de pago, 1921 & 64.137 .15 \\
\hline De vigencias expiradas & 17.094 .97 \\
\hline Banco López & 80.000 .00 \\
\hline Banco de Colombia & 31.923 .00 \\
\hline Total, de la deuda & $\$ 362.236 .90$ \\
\hline
\end{tabular}

Pasivos que pesaban sobre la Tesorería a 31 de diciembre de 1921

Nota: Elaborada a partir de (Alcaldía Municipal de Bogotá, 1924), p. 109

Mediante el Acuerdo 13 de 1921, el Concejo Municipal de Bogotá estableció un nuevo documento de crédito, que denominó: "Bono del Tranvía Municipal de Bogotá", destinado a cambiar los títulos existentes en esa época sobre el Tranvía, en el cual se reglamenta que "el municipio reconozca que debe al portador la cantidad de dinero que en él se exprese" (Concejo Municipal, 1921, Art. 1), el interés reglamentado para estos bonos fue del $10 \%$ anual, pagadero por meses vencidos en relación a la fecha de su emisión. Por este mecanismo el Concejo autorizó la emisión de bonos por un valor de $\$ 905.000$, de los cuales $\$ 823.657$, tenían como objetivo la conversión de la deuda del Municipio por vigente en razón de los empréstitos hechos para la adquisición del Tranvía municipal; los restantes $\$ 80.000$, serían destinados a la compra de un lote. (Alcaldía Municipal de Bogotá, 1924, p. 109. )

\subsubsection{Empréstito de la Casa Bancaria Dillon Read \& Co. de 1924}

Mediante escritura 1966 del 5 de noviembre de 1924 de la Notaría Tercera de Bogotá se solemnizó el contrato celebrado, entre el municipio de Bogotá y la casa bancaria Dillon Read y Co. de los Estados Unidos, "mediante el cual se pactó el préstamo de \$10.000.000, aprobado mediante Acuerdo 45 del 8 de octubre de 1924 por el Consejo (sic) Municipal' (Alcaldía Municipal de Bogotá, 1924, pág. 4). Este Acuerdo fue motivado en la necesidad de realizar algunas obras de importancia para la ciudad; como el ensanche y terminación del acueducto municipal, la construcción y equipo del matadero público municipal, la extensión del tranvía y construcción de su planta de fuerza eléctrica, la mejora del servicio de higienización de la ciudad, la ampliación y mejora de las plazas de mercado público, la construcción de viviendas para obreros, la construcción de edificios para escuelas públicas; y la necesidad de pagar la suma de $\$ 2.225 .000$, que el municipio había adquirido en préstamo con el objeto de atender a la compra y desarrollo de algunas de las anteriores obras. (Alcaldía Municipal de Bogotá, 1924, pág. 5). 
En las condiciones del contrato el Municipio pactó el crédito mediante una emisión inicial de seis millones de pesos $\$ 6.000 .000$, representados por bonos y una emisión potencial de cuatro millones de pesos $\$ 4.000 .000$ para garantizar el referido empréstito contratado con la Casa Dillon, Read \& Co, con el producido bruto de las rentas de las empresas procedentes del tranvía municipal, con su planta de luz y fuerza motriz, el acueducto, los mercados públicos, matadero público, edificio de propiedad municipal ocupado por la policía nacional, el producido bruto de todas las rentas de los bienes que en adelante adquiriera, ensanchara o construyera el municipio, con el producto del empréstito y las entradas brutas procedentes de las contribuciones sobre bienes raíces del municipio, tales como el impuesto predial, incluyendo los servicios de aseo, alumbrado y vigilancia (Alcaldía Municipal de Bogotá, 1924, pág. 8). Los bonos emitidos tendrían vigencia hasta octubre 1 de 1945, se denominaron "bonos externos de 1924, con fondo de amortización, pagaderos en oro, con interés del (8 por 100)" (Alcaldía Municipal de Bogotá, 1924, pág. 10)

En el contrato, están descritas las propiedades municipales cuyas rentas brutas garantizan los bonos que se emiten conforme al mismo entre las cuales se describe la Empresa del Tranvía en los siguientes términos: "Constituyen esta empresa todos los carros que hacen el servicio de transporte dentro de la ciudad, carrileras, edificios, terrenos, caídas de agua, herramientas, aparatos y demás accesorios, y sus plantas de fuerza y luz eléctrica instaladas en el local número veintidós (22) de la calle veintiséis (26) de esta ciudad. Dicha empresa fue adquirida por compra hecha por el municipio de Bogotá a las sociedades denominadas The Chapinero Company y The Bogotá City Reailway Company, por medio de la escritura número novecientos cuarenta y nueve (949) de fecha siete (7) de diciembre de mil novecientos diez (1910) otorgada ante el notario tercero de esta ciudad" (Alcaldía Municipal de Bogotá, 1924, pág. 35).

Asimismo, el Municipio conviene en celebrar un contrato o varios contratos para las obras de construcción e ingeniería, las cuales se sufragarán con el producto de los bonos, con Ulen \& Company de la ciudad de Nueva York y "sobre los términos que no fueren menos favorables al Municipio que el costo verdadero de dichas obras más el diez por ciento (10 por 100) de gratificación" (Alcaldía Municipal de Bogotá, 1924, pág. 32).

Durante este periodo los gastos de explotación que crecían de manera uniforme en los años anteriores a partir de 1924 experimentaron un incremento inusual. En los años 1920, 21, 22 y 23, los gastos representaron un 47, 48, y 47 por ciento respectivamente de los ingresos brutos; para el año 1924 ascendieron a más del $60 \%$ llegando en 1925 al $69 \%$ y sin que regresaran a menos del $55 \%$, afectando el producto neto.

\subsubsection{El crédito con los bancos: Bogotá, Colombia e Hipotecario}

A pesar de la fuerte competencia entre tranvía y buses, esta administración del tranvía saneo parcialmente las finanzas. Según estudios comparativos presentados por Ricardo Esquivel en Economía y Transporte Urbano en Bogotá 1884 1930, el tranvía presenta un porcentaje de costos del $44.8 \%$, mientras los buses presentan costos de $91.2 \%$, sin embargo, esta ventaja no fue suficiente para mantener la supremacía del tranvía, entre otras razones porque gran parte de la utilidad de éste fue utilizada para pavimentar vías para los buses, que en últimas se tradujo en una competencia desleal con desventaja del primero. Así, mientras la Empresa del Tranvía debía construir un carrileras, estaciones, cubrir seguros de accidente y muerte, y pensiones de su personal, las empresas de buses ni contribuían con la pavimentación como tampoco protegían a sus empleados, ni mucho menos respondían por accidentes de usuarios (Esquivel, 1997), p. 54.

\subsection{La Administración del Tranvía}

Durante el periodo de estudio, el tranvía perteneció al municipio, a pesar de su administración por agentes externos y a pesar de los pasivos adquiridos con diversas personas o entidades. Su administración se realizó a través de cinco figuras de juntas, en las que estaban incluidos principalmente los representantes de las personas con quienes en cada uno de estos momentos la empresa adquirió créditos.

Es ahí donde los actores privados entran a jugar papel determinante, sin que ello cambie el carácter público de la Empresa. La Junta como Institución en periodos anteriores al siglo XIX tiene diversas connotaciones, efectivamente la ciudad, particularmente el caso del tranvía, estuvo a cargo de juntas surgidas del sector privado con dominio en los principales servicios municipales. En esta forma de organización se sintetiza la relación entre lo público y lo privado como elemento de modernización de la administración de la ciudad.

\subsubsection{Junta Mantenedora de Tráfico}

Con el ánimo de mantener el boicot iniciado el siete de marzo de 1910, se creó la "Junta Mantenedora de Tráfico", con gran importancia en la municipalización y como un híbrido: ciudadanía - estado, surgió del 
descontento general, su objeto fue mantener el boicot el tiempo necesario para la nacionalización de la empresa.

\subsubsection{Junta de Comerciantes Ad Honorem}

El artículo 2 del Acuerdo 27 del 23 de septiembre de 1910, estableció crear una Junta compuesta de 10 individuos del comercio de la ciudad para que procediendo con absoluta autonomía y ad honorem organizara y administrara la empresa del tranvía; Junta a la cual se hizo entrega de la empresa una vez adquirida por el Municipio (Acuerdo 27, 1910) Art. 2.). En efecto, el 8 de octubre de este mismo año fue puesta bajo su administración en un comienzo con servicio prestado por carros de mulas en la línea Chapinero, luego haciendo uso del servicio eléctrico (Alcaldía de Bogotá, 1913, pág.3).

Los informes de la Alcaldía Municipal señalan la importancia de la empresa del tranvía en las finanzas de la ciudad, entre ellas el apoyo a la construcción de obras públicas, para el Concejo Municipal: "en primer término la adquisición del Acueducto, siendo así que sin agua potable y suficiente es del todo imposible acceder a cualquier obra como la del matadero, la plaza de mercado, etc., de que tanta necesidad tiene la ciudad". Así mismo resalta su prosperidad señalando que: "el presupuesto de la Empresa del Tranvía que se fijó en la suma de $\$ 196.960$, para la vigencia en curso, ha subido a $\$ 264.000$ parla vigencia próxima" (Alcaldía de Bogotá, 1913, pág.2 -5)

De otra parte, mediante Acuerdo 22 de 1913, fruto entre otras motivaciones de que: "La causa del lento progreso de la ciudad se debe a que el municipio no es dueño del Acueducto, pues siéndolo, se podría acometer la construcción de un abasto de agua científico" el Concejo Autorizó a la Junta Administradora del Tranvía a contratar un empréstito en Colombia por "un millón y medio de pesos (\$1.500.000) oro al ocho por ciento de interés anual con el cinco por ciento de amortización y el cinco por ciento de descuento inicial, dando en garantía las empresas del Tranvía Municipal y del Acueducto. El detalle del crédito se encuentra en un prospecto presentado por la Junta Administradora del Tranvía" (Concejo Municipal de Bogotá, 1913).

El Informe de la Alcaldía Municipal de 1915, hace un análisis hasta esa fecha y señala que: "El creciente producido de aquella dependencia municipal ( $\$ 264.000$ calculado para 1914 , contra $\$ 196.960$ calculado para 1913) demuestra progresiva valorización que alcanza a responder por una suma a lo menos tres veces mayor a la de su precio de compra" (Alcaldía de Bogotá, 1913, pág.2 -5.

Hacia 1915, continua el esquema de Junta inicialmente concebida, "La inmediata administración de la Empresa está a cargo de una Junta Directiva compuesta de dos miembros de la Junta Administradora y del Gerente" (Junta Administradora del Tranvía, 1915, p.3)

\subsubsection{Junta por Elección y con Honorarios}

A la par con la autorización de la emisión de los bonos del tranvía de 1921, el Artículo 11 del Acuerdo 13 de 1921, establece reorganizar la Junta Administradora del Tranvía, creada por el Acuerdo número 27 de 1910 y sus adicionales, en la siguiente forma: "quedará constituida por cinco miembros principales y cinco suplentes personales, elegidos por tres años, por el Consejo (sic) Municipal, por el sistema del voto incompleto y desde el próximo mes de septiembre. Los miembros de la Junta tendrán una remuneración de cinco pesos por cada sesión ordinaria a que concurran" (Concejo Municipal, 1921, Art. 11)

Hacia 1923, el informe del presidente del Concejo señala que: "como es sabido, la Empresa del Tranvía goza de relativa autonomía y está administrada por una Junta compuesta de cinco miembros, elegidos todos por el Concejo. El Gerente, según el Acuerdo número 13 de 1921, era elegido por ella, pero el Concejo actual creyó conveniente modificar esta disposición y, en efecto, por el Acuerdo número 19 de 1922 reasumió la facultad para designarlo" (Concejo Municipal de Bogotá, 1923).

\subsubsection{Junta de la Dirección de las Empresas Municipales}

Hacia 1924, surge una fuerte crisis con antecedente en los hechos del 16 de marzo de 1924 cuando resultó muerto un conductor del tranvía a manos de un superintendente resultado de tensiones previas por despidos de algunos empleados del tranvía. Como reporta el diario El Tiempo estalló la huelga sin saber siquiera sus autores, pues nadie había pensado organizar un paro. La protesta se extendió hasta el 23 de abril de 1924, fecha en la que se llegó a acuerdos en las negociaciones (Diario El Tiempo, abril 23 de 1924, pp. 1 y 4). Una revisión general de sus peticiones, desvirtúa el argumento sobre el posible efecto nocivo del Sindicato sobre 
la rentabilidad de la empresa, dado que estas se limitaban a exigencias democráticas, normales de una empresa formal, abarcan las necesidades mínimas de un trabajador moderno. Sin embargo, en relación con la competencia de buses significaba una gran desventaja, pues estas empresas crecían en medio de la informalidad.

Las políticas del Estado orientadas a la adquisición de préstamos y específicamente las obligaciones adquiridas con el crédito de la de la Casa Dillon, exigió modificaciones en la estructura de la empresa del tranvía, entre otras las establecidas en el acuerdo 47 de 1924.

La fusión de las Empresas Municipales se formalizó mediante del Acuerdo 57 de diciembre 26 de 1924 fruto de las mismas obligaciones. En su Artículo 1, establece: "Créase una junta que se denominará Dirección de las Empresas Municipales; la cual tendrá a su cargo la organización, manejo dirección y administración del acueducto, del tranvía, de las plantas eléctricas municipales y de las demás empresas industriales que el municipio establezca. La Junta creada por este Acuerdo, complementada con el señor director de obras públicas municipales, quien tendrá voz en ella, formará en asocio de los ingenieros de la casa Ulen \& Co el plan general de las obras que deben ejecutarse según el contrato aprobado por el Acuerdo 55 de 1925 y someterá ese plan a la aprobación del Concejo" (Concejo Municipal,1924).

Hacia 1925 surgen nuevas crisis que en su momento fueron atribuidas a posibles irregularidades de la Junta anterior (Diario El Tiempo, febrero 6 de 1925, p. 6), igualmente surgían frecuentes quejas por la mala prestación del servicio, que fue atribuida a la "faceta pública de un estado interno caótico en la administración financiera y técnica de la empresa" (Diario El Tiempo marzo 3 de 1925, p.1). Este mismo año, marcó un punto de quiebre de baja rentabilidad de la empresa productos de altos costos de funcionamiento, el Concejo halló la causa en que "la administración unificada [...] insuficiente para atender a todos los detalles propios de la labor y por ello [...] necesaria la división del trabajo y la especialización". Diagnosticó "no [...] conveniente la refundición (sic) de empresas de índole distinta en una. Para [...] ejemplo [...] las grandes empresas de los Estados Unidos". La decisión: "la administración conjunta de las empresas municipales queda dividida en tres departamentos: hacienda, acueducto y tranvía." (Diario El Tiempo marzo 3 de 1925, p.1)

Hacia 1929, se generó una nueva crisis en la Empresa del Tranvía, al parecer basada en la corrupción, la cual se resolvió con la dimisión del gabinete, cambió al gobernador de Cundinamarca y al alcalde de Bogotá y a los gerentes del acueducto y tranvía. (Montaña Cuellar, Diego, Memorias, pág. 108).

\subsubsection{Junta de Administración Delgada}

Mediante el Acuerdo 15 de 1929 el Concejo Municipal, aprueba el contrato celebrado con los Bancos de Bogotá, Colombia e Hipotecario de Colombia, sobre administración delegada de las Empresas del Tranvía y Acueducto, soportado en la Ordenanza 42 de 1913, y la Ley 72 de 1926, se inicia una nueva etapa de Administración del Tranvía. A partir de ese momento la Junta directiva se compone de cinco miembros, tres por los Bancos contratantes, uno por el Concejo municipal y el Alcalde de la ciudad. (Concejo Municipal, 1926 Art. 1, núm. 2)

\section{CONCLUSIONES}

El tranvía antes de la municipalización pertenecía al sector privado, luego de está pertenece al público, aunque con dinero proveniente del sector privado a través de préstamos nacionales e internacionales. La municipalización del tranvía promovida por presión social estremeció la ciudad en todas las esferas. De lo encontrado en la investigación se resalta el impacto económico que significó para el municipio adquirir la empresa que entra a su presupuesto a representar entre un $41 \%$ y un $45 \%$ de sus finanzas. Hay una modificación sustancial del papel que juegan los actores privados en la economía de la ciudad, hay una apropiación diferente de la renta por parte de los privados que ahora no se benefician de utilidades, sino de intereses; y se da un beneficio enorme del sector público al adquirir un activo que crece significativamente por encima del pasivo que, aunque se mantiene no es comparable frente al desarrollo físico y funcional de la empresa que permanece en crecimiento.

Se destaca la mutación institucional que se da en el manejo de los servicios de la ciudad a través de juntas. La junta como rueda clave en el engranaje del gobierno de la ciudad. En la Junta confluyen los representantes del sector privado y del sector público para decidir el funcionamiento de una empresa de la ciudad controlada 
por la ciudad y vigilada por las instituciones de fiscalización de la ciudad. Por primera vez es la junta una forma de gobierno en la que se apoya la municipalidad para dar solución su movilidad cada vez más dinámica.

Sin embargo, es el sector privado quien mayoritariamente entra a controlar el funcionamiento del sistema, lo cual concuerda con la ausencia de planeación pública y de una visión vigorosa de ciudad por parte del sector público; en contraposición con intereses privados de promotores, propietarios e informales que son quienes encausan el crecimiento de la ciudad en medio de la anarquía y la usura capitalista

El carácter público y ejemplar dado por la a la empresa en los primeros 15 años de la municipalización lamentablemente fue empañado por el manejo por algunos integrantes de la junta vigente hacia 1925, que ocasionó la crisis de finales de los años 1920. Aun así, se prueba que es muy apropiado que un Estado transparente en representación de la ciudadanía sea el encargado del funcionamiento de los servicios vitales de la ciudad, pues son rentables y en ellos debería primar el interés general sobre el particular.

De acuerdo a la cartografía de la época es evidente que entre la forma de la ciudad y la forma del tranvía existió una alimentación recíproca, ya por la atracción que generaba la existencia del servicio, o por la necesidad de ampliar las redes de acuerdo a la demanda. Al estudiar la distribución y cobertura de las redes puede otorgarse un papel trascendente al este sistema de transporte; no así a la desconcentración de actividades, pues Bogotá, en el periodo de estudio mantuvo su carácter de ciudad monocéntrica, las fábricas, restaurantes, cafés y el asiento de los órganos de poder municipal y nacional, continuaron principalmente implantados en el centro decimonónico de la ciudad; más aún es posible afirmar que el tranvía favoreció el modelo de ciudad monocéntrica, pues su diseño siempre estuvo orientado a unir el centro con las periferias norte, sur y occidental de la ciudad.

\section{BIBLIOGRAFIA}

\section{Obra completa}

ACOSTA, R. J., \& BAQUERO, M. J. (2007). El Tranvía en Bogotá: Rutas y destinos, 1884 - 1951. Bogotá: Alcaldía Mayor de Bogotá.

ALCALDÍA DE BOGOTÁ. (1910). Informe de la Alcaldía de Bogotá y demás oficinas sobre la Administración del Municipio en el año de 1910. Bogotá: J. Casis.

(1913). Mensaje del Alcalde Municipal al Concejo Municipal, acompañando el presupuesto de rentas y gastos del municipio para 1914. Bogotá: Arboleda \& Valencia.

ALCALDÍA MUNICIPAL. (1913). Mensaje del Alcalde de Bogotá al Concejo Municipal. Acompañando el Presupuesto de Rentas y Gastos del Municipio para 1914. Bogotá: Arboleda \& Valencia.

ALCALDÍA MUNICIPAL DE BOGOTÁ. (1928). El Empréstito Municipal de 1924, Anexo a la Memoria Municipal de Bogotá Correspondiente al Bienio 1923 - 1925. Bogotá: Imprenta Municipal de Bogotá. BAQUERO MORA, J. I. (2009). Tranvía municipal de Bogotá. Desarrollo y transición al sistema de buses municipal, 1884 - 1951. Bogotá: Tesis Magister Historia de Colombia UN.

CONCEJO DE BOGOTÁ. (1921). Informe del Presidente del Concejo Municipal de Bogotá. Doctor A.

Manrique Martín ante la misma Corporación sobre las tareas de esta en su periodo de 19 de noviembre de 1919 a 31 de octubre de 1921. Bogotá: Imprenta Municipal.

(1929). Memoria Municipal de Bogotá, Informes Sobre las Labores de la Administración

Municipal en el Bienio de 1927 a 1929. Bogotá: Imprenta Municipal de Bogotá.

(1929). Memoria Municipal de Bogotá: Informes sobre las labores de la administración

municipal en el bienio 1926 - 1929. Bogotá: Imprenta Municipal Bogotá. (1919). Informe del Presidente del Concejo Municipal de Bogotá. Bogotá: Imprenta

Municipal.

(1925). Memoria Municipal de Bogotá; Mensaje del presidente del Consejo (sic)

Municipal, señor Francisco Samper Madrid, al pueblo de Bogotá y al nuevo personal del cabildo e informes de los jefes de las dependencias municipales. Bogotá: Imprenta Municipal.

CONCEJO MUNICIPAL DE BOGOTÁ. (1910). Registro Municipal. Bogotá: NN.

(1919). Informe del Presidente del Concejo Municipal de Bogotá.

Doctor Zoilo E. Cuellar B. ante la misma corporación sobre las tareas en su periodo de 1 de noviembre de 1917 a 31 de octubre de 1919. Bogotá: Imprenta Municipal. 
(1923). Mensaje del Presidente del Consejo (sic) Municipal de Bogotá doctor Federico Lleras Acosta ante la misma corporación sobre las tareas de esta en su periodo de 19 de noviembre de 1921 a 31 de octubre de 1923. Bogotá: Imprenta Municipal.

(1925). Mensaje del Presidente del Consejo Municipal, al Pueblo de Bogotá y al Nuevo Personal del Cabildo e Informes de los Jefes de las Dependencias Municipales Sobre Las Tareas de la Administración entre 1 de noviembre de 1923 y 31 de octubre de 1925. Bogotá: Imprenta Municipal.

CONTRALORÍA GENERAL DE LA REPÚBLICA. (1941). Censo General de Población 5 de Julio de 1938. Bogotá: Imprenta Nacional.

\section{Nueva.} (1930). Memorias y Cuadros del Censo de 1928. Bogotá: Librería

CONTRALORÍA GENERAL DE LA REPÚBLICA DIRECCIÓN DEL CENSO. (1930). Memorias y Cuadros del Censo de 1928. Bogotá: Editorial Librería Nueva.

CORTES SOLANO, R. (2007). Del Urbanismo a la Planeación en Bogotá (1900 - 1990), Esquema inicial y materiales para pensar la trama de un relato. Bitácora, 160-2013.

CUÉLLAR, M., \& MEJÍA, G. (2007). Atlas Histórico de Bogotá. Bogotá: Planeta.

DANE. (1955). Censo Nacional de Población de 1951. Bogotá D.C.: Departamento Administrativo Nacional de Estadística.

DEL CASTILLO, J. C. (2003). El Tránsito a la Ciudad Moderna 1920 - 1950. Bogotá D.C.: Guadalupe.

DI GAETANO, A. (2009). The Birth of Modern Urban Governance. A Comparison of Political Modernization in Boston, Massachussetts, and Bristol, England, 1800 - 1870. Journal of Urban History, 259- 288.

DIRECCIÓN NACIONAL DE ESTADÍSTICAS. (1952). Anuario Municipal de Estadísticas, Oficina Municipal. Bogotá: DANE.

DUPUY, G. (1992). El Urbanismo de Redes. París: Oikos Tau S.L.

ESGUERRA, P. (1922). Tranvía Municipal de Bogotá esquema que muestra la longitud y desarrollo de las líneas en 1922. Bogotá: Departamento de Ingeniería. Recuperado el 17 de noviembre de 2015, de http://www.banrepcultural.org/node/97261/zoomify

ESQUIVEL, T. R. (1997). Economía y Transporte Urbano en Bogotá 1884 - 1930. Memoria y Sociedad, Vol 2 No. $4,39-61$.

HALL, P. (1996). Ciudades del Mañana, Historia del Urbanismo en el Siglo XX (Primera Edición ed., Vol. 2). (F. Tarrega, Ed., \& C. Freixa, Trad.) Barcelona, Cataluña, España: Ediciones del Serbal. Recuperado el 30 de septiembre de 2014

(2013). Ciudades del Mañana. Barcelona: Ediciones del Serbal.

IZQUIERDO, A. (1900). Lotes en Chapinero con Grandes Plazos sin Pagar Intereses. Ventajas para los compradores Caja de Ahorros - Cuentos sobre lotes. Bogotá: Tipografía Salesiana.

JARAMILLO, S., \& PARIAS, A. (1995). Vida, Pasión y Muerte del Tranvía. Bogotá: CEDE.

Jorge E Hardoy, G. G. (1972). Políticas de Desarrollo Urbano y Regional de América Latina. Buenos Aires: Viamonte.

JUNTA ADMINISTRADORA DEL TRANVÍA. (1915). Informe General que rinde al Honorable Consejo Municipal en 1 de noviembre de 1915. Bogotá: Arboleda \& Valencia.

JUNTA ADMINISTRADORA DEL TRANVİA MUNICIPAL. (1913). Informe General que, al principiar el segundo periodo de su administración, rinde la Junta Administradora del Tranvía al H. Concejo Municipal. Bogotá: Talleres Tipográficos de Régulo Domínguez.

primaria referenciar bien). Bogotá: Concejo de Bogotá. (1918). Terrenos y Propiedades (es una fuente LÓPEZ, L. M., \& RESTREPO, M. G. (1985). Historia del tranvía. Bogotá: Tesis de Grado para optar al título de Licenciatura en Ciencias Sociales.

MEJíA PAVONY, G. R. (2000). Los Años del Cambio Historia Urbana de Bogotá 1820 - 1910. Bogotá: Centro Editorial Javeriano, CEJA.

MONTEZUMA, R. (2000). Presente y Futuro de la Movilidad Urbana en Bogotá. Bogotá: Centro Editorial Javeriano.

(2008). La Ciudad del Tranvía 1880 - 1920. Bogotá: Universidad del Rosario.

NÚÑEZ CETINA, S. C., \& RODRÍGUEZ BAQUERO, L. E. (2003). Empresas Públicas de Transporte en Bogotá Siglo XX (Vol. 1). Bogotá D.C.: Subdirección Imprenta Distrital de Bogotá.

REPÚBLICA DE COLOMBIA. (1941). Censo General de Población 5 de julio de 1938, Tomo VII, Departamento de Cundinamarca. Bogotá: Imprenta Nacional.

RODRíGUEZ, B. L., \& NÚÑEZ, C. S. (2003). Empresas Públicas de Transporte en Bogotá durante el siglo XX. Bogotá: Alcaldía Mayor de Bogotá D.C.

ROMERO, J. L. (1999). Latinoamérica: Las Ciudades y Las Ideas. Medellín: Universidad de Antioquia. 
SALAZAR, F. P. (2008). Redes de infraestructura y crecimiento urbano: Bogotá entre 1884 y 1951. Bogotá: Trabajo de Grado para optar al título de Magister en Urbanismo UN.

SÁNCHEZ, A., \& CORTES M, A. (15 de octubre de 1910). Resurrección del Tranvía. El Gráfico, Serie 2(13), 1-3. Suárez Mayorga, Adriana María. La ciudad de los elegidos: Crecimiento urbano, jerarquización social y poder político; Bogotá, 1910-1950. Bogotá: Editorial Guadalupe, 2006.

TOVAR, C. A. (2009). Ciudad Informal Colombiana: Barrios construidos por la gente. Bogotá: Universidad Nacional de Colombia.

URIBE, R. E. (1924). Bogotá Futuro. (I. d. Departamento, Ed.) Revista Técnica de Obras Públicas de Cundinamarca, 1-69. Recuperado el 09 de 12 de 2014

VARGAS, J., \& ZAMBRANO, F. (1988). Bogotá 450 años Retos y Realidades. Bogotá: Foro Nacional por Colombia.

\section{Capítulo de libro}

MEJÍA PAVONY, G. (2011). En busca de la intimidad (Bogotá, 1880 - 1910). En J. B. Jiménez, Historia de la Vida Privada en Colombia, Tomo II: Los signos de la intimidad El Largo Siglo XX (págs. 19-47). Bogotá: Tauros.

\section{Revistas}

ALBA CASTRO, J. M. (diciembre de 2013). El plano Bogotá Futuro. Primer intento de modernización urbana. Revista Anuario Colombiano de Historia Social y de la Cultura (ACHSC), 40(2), 1-16. FUNDACIÓN MISIÓN COLOMBIA. (1986). Historia de Bogotá Tomo II. Bogotá: Villegas Editores. GONZÁLEZ, M., \& PEREIRA, F. (1898). Tranvía de San Cristóbal, prospectos y escrituras. Bogotá: Papelería de Samper y Matiz.

MEJÍA, P. G. (1997). Los Itinerarios de la Transformación Urbana Bogotá, 1820 - 1910. Bogotá: Anuario Colombiano de Historia Social y de la Cultura 24.

\section{Ordenanzas o Decretos}

Acuerdo 12 (6 de noviembre de 1883).

Acuerdo 22 (28 de octubre de 1882).

Acuerdo 27 (23 de septiembre de 1910).

Concejo Municipal. (1910). Acuerdo 32. Bogotá: Concejo Municipal.

Concejo Municipal. (1921). Acuerdo 13. Bogotá: Concejo de Bogotá.

Concejo Municipal. (1924). Acuerdo 57. Bogotá: Concejo Municipal.

Concejo Municipal. (1926). Acuerdo 15. Bogotá: Concejo Municipal.

Concejo Municipal de Bogotá. (1915). Acuerdo 11. Bogotá: Concejo Municipal.

\section{Fuentes electrónicas}

http://cartografia.bogotaendocumentos.com/

http://mapwarper.net/maps 